\title{
New species of deep-water Calcigorgia gorgonians (Anthozoa: Octocorallia) from the Sea of Okhotsk, with a re-diagnosis and a taxonomic review of the genus
}

\author{
Tatiana N. DAUTOVA \\ A.V. Zhirmunsky National Scientific Center of Marine Biology, Far Eastern Branch, \\ Russian Academy of Sciences, Vladivostok 690041, Russia. \\ Email: tndaut@mail.ru
}

urn:1sid:zoobank.org:author:76084673-E4B7-4BF6-88E3-66B297CB3E22

\begin{abstract}
This paper provides descriptions of two new species of Calcigorgia gorgonians collected from the Sea of Okhotsk between 1973 and 2008. The new species are Calcigorgia herba sp. nov. and C. lukini sp. nov., belonging to the deep-water coral fauna of the temperate Northern Pacific. The taxonomy structure of the genus is reviewed and a comparative table is provided for all known species of Calcigorgia. The following taxonomic changes are made: the diagnosis of the genus was corrected from that given in Matsumoto et al. (2019); synonymization of C. simushiri Dautova, 2018 with C. spiculifera Broch, 1935 and inclusion of additional specimens in C. japonica Dautova, 2007 (both performed by Matsumoto et al. 2019) are assumed erroneous. The finding of previously undescribed species emphasizes the need for further surveys, particularly in deeper waters, to improve knowledge of the Octocorallia fauna in Far East seas. The distribution of Calcigorgia (Octocorallia, Acanthogorgiidae) is reviewed and presented based on field and collection studies published since 1935 as well as miscellaneous data from previous literature.
\end{abstract}

Keywords. Calcigorgia herba sp. nov., Calcigorgia lukini sp. nov., taxonomy, sclerites, distribution.

Dautova T.N. 2019. New species of deep-water Calcigorgia gorgonians (Anthozoa: Octocorallia) from the Sea of Okhotsk, with a re-diagnosis and a taxonomic review of the genus. Europaean Journal of Taxonomy 549: 1-27. https://doi.org/10.5852/ejt.2019.549

\section{Introduction}

Due to their long lifespan and slow recovery from physical damage, deep cold-water corals attract attention as important components of vulnerable marine ecosystems. Their importance includes their role as nurseries for fish larvae (Baco \& Shank 2005; Roberts et al. 2006; Baillon et al. 2012; Miyamoto et al. 2017). Species of the order Octocorallia, like other corals, provide biogenic substrata. They can be found from tropical shallows to polar and deep-water environments, even deeper than $6000 \mathrm{~m}$ (Williams 2011; Zapata-Guardiola \& Lopez-Gonzalez 2010). The complex three-dimensional biogenic substrata provided by cold-water Octocorallia, mostly gorgonians, support a very high level of biodiversity similar to that of coral reefs (Buhl-Mortensen \& Mortensen 2004, 2005; Auster et al. 2005; Roberts et al. 2006; 
Parrish \& Baco 2007; Buhl-Mortensen et al. 2016). There are vast regions around the world where very little collecting has been done, such as the Arctic, the Sea of Okhotsk and the western part of the Bering Sea (Pérez et al. 2016; Dautova 2018a). One of these regions is the area around the Sakhalin Island and the Kurile Islands (Northwest Pacific), from where only a few deep-water gorgonian genera have been recorded (Broch 1935; Dautova 2012, 2018a, 2018b; Matsumoto et al. 2019). Among these, Calcigorgia Broch, 1935 was described as a new gorgonian genus (with a single species, Calcigorgia spiculifera Broch, 1935), based on material collected at depths of 150-165 m near the northern part of the Sakhalin

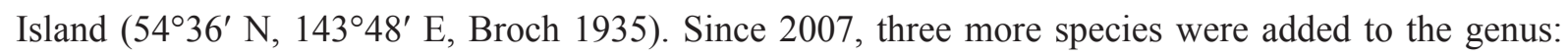
Calcigorgia japonica Dautova, 2007, C. matua Dautova, 2018 and C. simushiri Dautova, 2018. Later, four species were added to the genus by Matsumoto et al. (2019). The present paper provides new data on this genus, collected by the Russian Academy of Sciences and the Pacific Fisheries Research Center during a series of expeditions in the second half of the 20th century. Descriptions of the new species enlarge our knowledge of the distinctive taxonomic characters for the genus and provide new data on its distribution. The taxonomic importance of some characters is discussed.

Data on the distribution of the representatives of the genus are summarized based on field data and the literature.

\section{Material and methods}

The samples were collected by dredging and fixed in $70 \%$ ethanol during field expeditions of the Pacific Fisheries Research Center (PFRC) and the National Scientific Centre of Marine Biology (NSCMB, formerly Institute of Marine Biology) of the Far Eastern Branch of the Russian Academy of Sciences (1973, 1987, RV Tikhookeansky; 2008, RV Akademik Oparin). Specimens belonging to both new species are registered in the Museum of the Institute of Marine Biology, National Scientific Center of Marine Biology FEB RAS, Vladivostok, Russia (MIMB). The tissue samples of the following different colony parts were examined separately: tentacles, polyp body wall, and coenenchyme. The organic matter in the samples was removed using sodium hypochlorite. The sclerites were washed from hypochlorite with distilled water and ethanol (70\%) and, after drying in air, were mounted on carbon double adhesive tape and carbon coated. Images of the sclerites were obtained with scanning electron microscopy (SEM, a Zeiss Evo 40, Far East Center of Electron Microscopy, Vladivostok, Russia) with optimal magnification for each sclerite size. The sclerite types recognized in the studied specimens are named in accordance with Bayer et al. 1983. Specimens of the species Calcigorgia spiculifera, C. japonica, C. matua and C. simushiri, whose sampling data are in Dautova (2018b), were used for comparison. Comparative material is stored in MIMB and in the Zoological Institute RAS in St.-Petersburg, Russia.

\section{Repositories}

MIMB = Museum of the Institute of Marine Biology, National Scientific Center of Marine Biology FEB RAS, Vladivostok, Russia

ZIN = Zoological Institute RAS, St.-Petersburg, Russia 


\section{Results}

Phylum Cnidaria Verrill, 1865

Class Anthozoa Ehrenberg, 1834

Subclass Octocorallia Haeckel, 1866

Order Alcyonacea Lamouroux, 1812

Suborder Holaxonia Studer, 1887

Family Acanthogorgiidae Gray, 1859

Genus Calcigorgia Broch, 1935

\section{Diagnosis}

Acanthogorgiid gorgonians whose sclerites are not individually conspicuous and not regularly arranged in the polyp. Sclerites are spindles, capstans, ovals, and clubs with warty, leafy, or serrated heads.

\section{Remarks}

The diagnosis given above combines those provided by Broch (1935) and Bayer (1981), and adds the cases when clubs with leafy or serrated (dentate) heads are present. Leafy clubs were shown for Calcigorgia matua, C. herba sp. nov. and C. lukini sp. nov. Clubs with serrated heads were found in C. japonica and in some specimens of Calcigorgia from Matsumoto et al. (2019). Matsumoto et al. (2019) also gave a diagnosis of the genus, but they wrongly noted that "tentacular sclerites are scales or absent; polyp and coenenchymal sclerites in the form of stout tuberculate spindles" (Matsumoto et al. 2019: 2-3). Calcigorgia spiculifera, the type of the genus, has not only scales but also clubs and spindles in the tentacles. Its polyp body and coenenchyme with capstans and ovals (Broch 1935: 22-25, fig. 14; Table 1 of the present paper). Additionally, various sclerite types besides the scales were documented in tentacles and other parts of colonies of a range of Calcigorgia representatives, including those described in Matsumoto et al. 2019 (Table 1 of the present contribution).

\section{Calcigorgia herba sp. nov. urn:1sid:zoobank.org:act:D44ADB76-6A55-466F-B41F-1123D3C34534}

Figs 1-7; Table 1

\section{Diagnosis}

Calcigorgia colonies scantly branched, with long smooth stem. Polyps in alcohol-preserved material up to $3 \mathrm{~mm}$ high and up to $2 \mathrm{~mm}$ wide, crowded in distal parts of colonies, arranged irregularly on the surface of the colony. Polyp body wall cylindrical in shape and with smooth surface. Polyp tentacles with scales, warty rods and clubs, poorly developed clubs with leafy processes on head, spindles, capstans (8-radiate) and ovals. Polyp body walls with warty clubs, club-like warty spindles, warty spindles, poorly developed clubs with leafy processes on head, ovals, and capstans (8-radiate). Coenenchyme with capstans (8-radiate) and ovals.

\section{Etymology}

The specific epithet 'herba' is due to a shape of colonies similar to a plant with a stalk in the form of a hollow straw and with small flower-like protrusions reminiscent of ears of corn or tussocks.

\section{Material examined}

\section{Holotype}

SEA OF OKHOTSK - Kurile Islands • $135 \times 13 \mathrm{~mm}$; Matua Is.; expedition of PFRC, NSCMB, and ZIN RAS on RV Tikhookeansky, station 306, sample 895; 4801' N, $153^{\circ} 22^{\prime}$ E; depth 100 m; 18 Aug. 1987; V. Lukin leg.; dredged; MIMB 20744. 


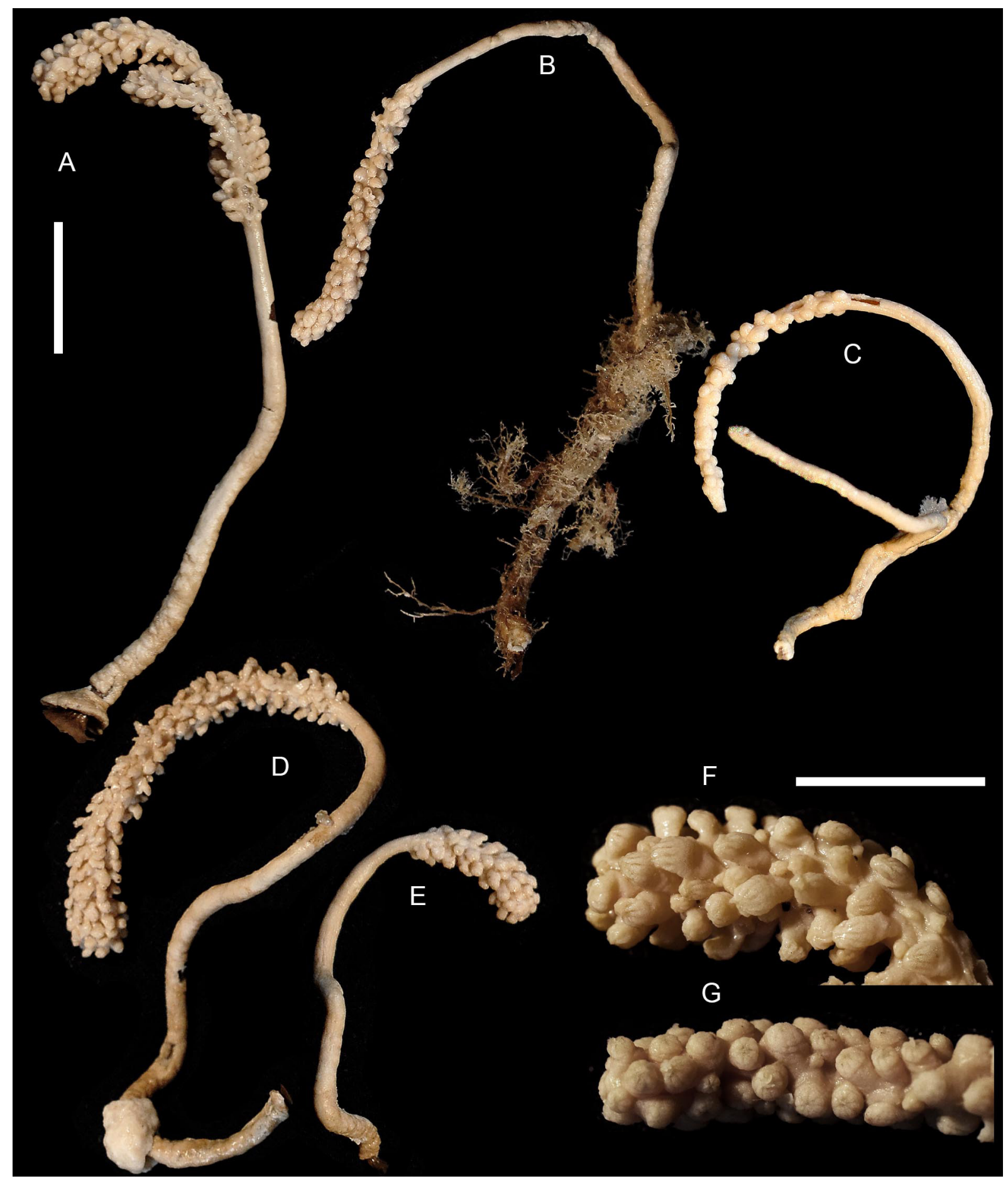

Fig. 1. Calcigorgia herba sp. nov. A. Holotype MIMB 20744, Kurile Islands, Sea of Okhotsk. B. Paratype MIMB 20745, Kurile Islands, Sea of Okhotsk. C. One specimen, Kurile Islands, Sea of Okhotsk, MIMB 20709. D-E. Two specimens, Kurile Islands, Sea of Okhotsk, MIMB 20748. F. Terminal polyps, holotype MIMB 20744. G. Terminal polyps, paratype MIMB 20745. Scale bars: $A-E=20 \mathrm{~mm} ; \mathrm{F}-\mathrm{G}=10 \mathrm{~mm}$. 


\section{Paratype}

SEA OF OKHOTSK - Kurile Islands • $159 \times 9$ mm; Matua Is.; expedition of PFRC, NSCMB, and ZIN RAS on RV Tikhookeansky, station 306, sample 895; 48 ${ }^{\circ} 1^{\prime}$ N, $153^{\circ} 22^{\prime}$ E; depth 100 m; 18 Aug. 1987; V. Lukin leg.; dredged; MIMB 20745.

\section{Additional material}

SEA OF OKHOTSK - Kurile Islands • 1 specimen; Rikord Str.; cruise on RV Tikhookeansky; $47^{\circ} 18^{\prime} \mathrm{N}$, 152 34' E; depth 100 m; 18 Jul. 1987; S. Grebelniy leg.; dredged; MIMB $20684 \bullet 1$ specimen; Urup Is.; station 420; $46^{\circ} 19^{\prime} \mathrm{N}, 150^{\circ} 42^{\prime} \mathrm{E}$; depth 100 m; 12 Sept. 1973; MIMB $20688 \bullet 1$ specimen; Ketoy Is.;

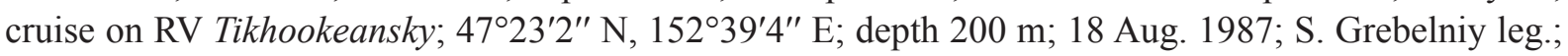
MIMB 20694 • 1 specimen; Urup Is.; cruise on RV Tikhookeansky; 46²19' N, 150 42' E; V. Lukin leg.; MIMB 20709 1 specimen; Diana St., between Simushir Is. and Ketoy Is.; cruise on RV Tikhookeansky, station 289, sample 846; $47^{\circ} 15^{\prime} 8^{\prime \prime} \mathrm{N}, 152^{\circ} 28^{\prime} 1^{\prime \prime} \mathrm{E}$; depth $75 \mathrm{~m} ; 17$ Aug. 1987; MIMB 20746 • 1 specimen; Rasshua Is.; cruise on RV Tikhookeansky, station 300, sample 877; 48 $01^{\prime} \mathrm{N}, 153^{\circ} 22^{\prime} \mathrm{E}$; depth 100 m; 12 Aug. 1987; MIMB 20747 • 2 specimens; Ketoy Is.; cruise on RV Tikhookeansky; 47²3'2" N, 152³9'4" E; depth 200 m; 18 Aug. 1987; S. Grebelniy leg.; MIMB $20748 \bullet 1$ specimen;

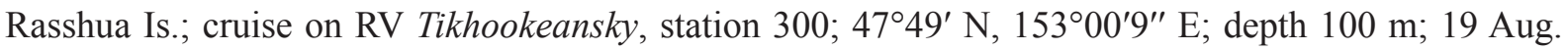
1987; V. Lukin leg.; MIMB 20749.

\section{Description}

\section{Holotype}

Colony scantly branched (Fig. 1A), with long smooth stem. Polyps crowded in the distal part of colony, arranged irregularly on the surface of the colony (Fig. 1F).

Colony $135 \mathrm{~mm}$ high and $13 \mathrm{~mm}$ wide (Fig. 1A). Polyps up to $3 \mathrm{~mm}$ high and $2 \mathrm{~mm}$ wide. Polyp body wall cylindrical in shape, with smooth surface; tentacles folded over polyp, partly retracted to inside (Fig. 1F).

Coenenchyme $0.5 \mathrm{~mm}$ thick and consists of two layers, a $0.4 \mathrm{~mm}$ thick outer layer, with smooth surface, and a very thin inner layer. Axis with concentric layers; no mineralization observed. Sclerites unordered in tentacles, polyp body wall and coenenchyme.

Tentacles contain small warty rods, scales, warty spindles, clubs, capstans and ovals. Warty spindles, up to $0.11 \mathrm{~mm}$ long (Fig. 2A). Scales, up to $0.11 \mathrm{~mm}$ long, flattened, with notched edges (Fig. 2B). Warty spindles, up to $0.22 \mathrm{~mm}$ long, with tall and asymmetrically developed processes (Fig. 2C). Warty clubs mainly $0.12-0.2 \mathrm{~mm}$ long, with plump warty heads and straight warty handles (Fig. 2D). Smaller clubs, up to $0.15 \mathrm{~mm}$ long, poorly developed (Fig. 2E). Their handles short and thick, blunt, bearing small crowded warts; the heads consist of notched leafy processes (Fig. 2E). Club-like spindles, up to $0.23 \mathrm{~mm}$ long, with some accumulation of processes on one end (Fig. 2F) and warts tending to be girdled. Capstans (8-radiate), usually up to $0.12-0.14 \mathrm{~mm}$ long, not numerous (Fig. 2G). Some well calcified capstans, up to $0.16 \mathrm{~mm}$ long, transitional to warty ovals. These ovals, up to $0.19 \mathrm{~mm}$ long, bear crowded warts tending to be conjunct (Fig. 2H).

Polyp body wall with warty clubs, mainly $0.15-0.18 \mathrm{~mm}$ long, with plump head consisting of warty processes (Fig. 3A). Shorter clubs, up to $0.16 \mathrm{~mm}$ long, poorly developed, with notched leafy processes on heads; handles of short clubs thick and covered with small warts (Fig. 3B). Longer clubs transitional to club-like spindles, up to $0.16 \mathrm{~mm}$ long, with some accumulation of warts on one end (Fig. $3 \mathrm{C}$ ). Plump spindles, up to $0.21 \mathrm{~mm}$ long, straight, with warts tending to be girdled (Fig. 3D). Short clubs also coincide with ovals, mostly $0.14-0.16 \mathrm{~mm}$ long, densely covered by unordered warts (Fig. 3E), 


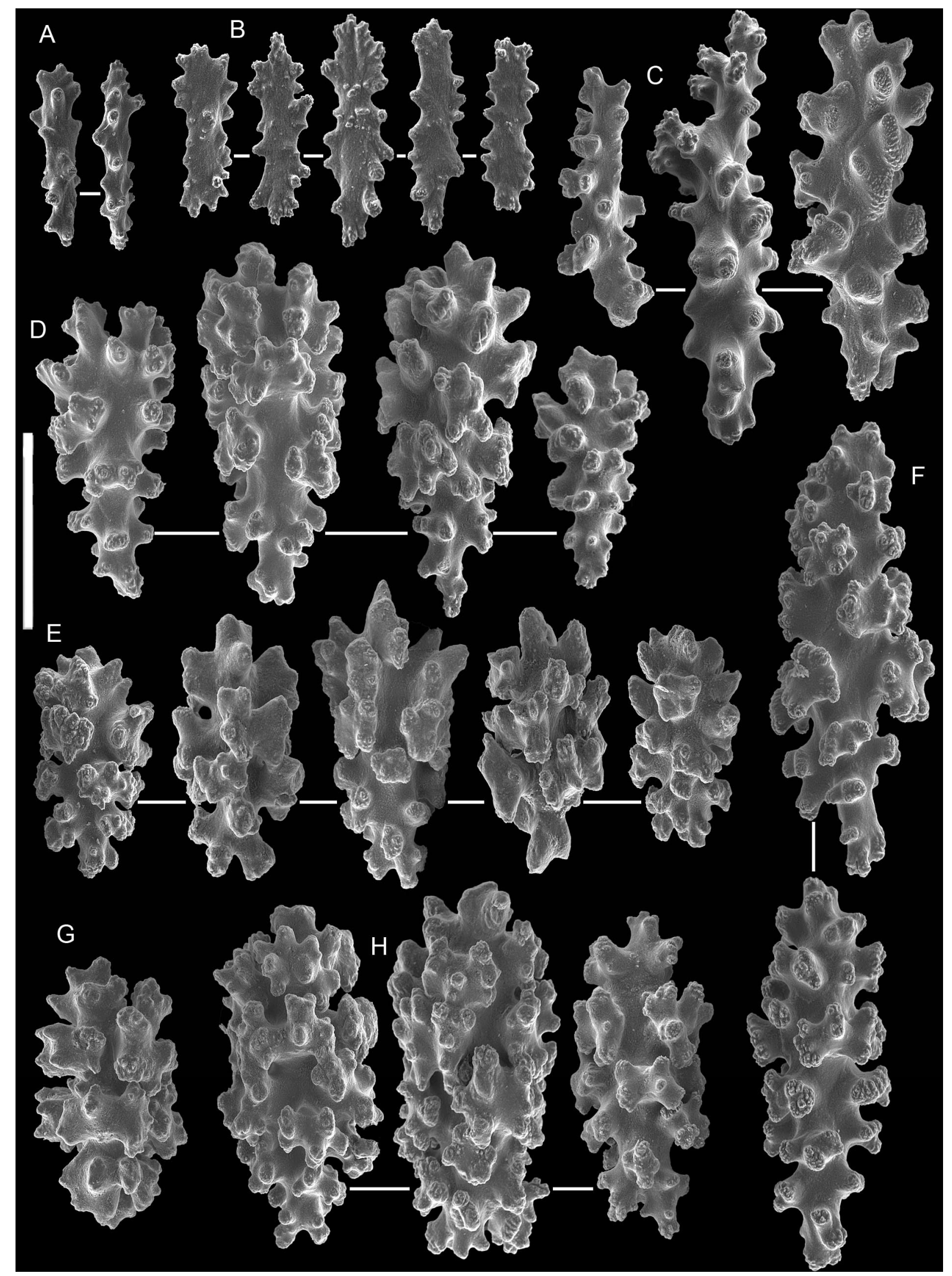

Fig. 2. Calcigorgia herba sp. nov., holotype MIMB 20744, sclerites from the tentacles. A. Rods. B. Scales. C. Warty spindles. D. Warty clubs. E. Poorly developed clubs with serrated processes. F. Club-like spindles. G. Capstan (8-radiate). H. Ovals. Scale bar $=0.1 \mathrm{~mm}$. 


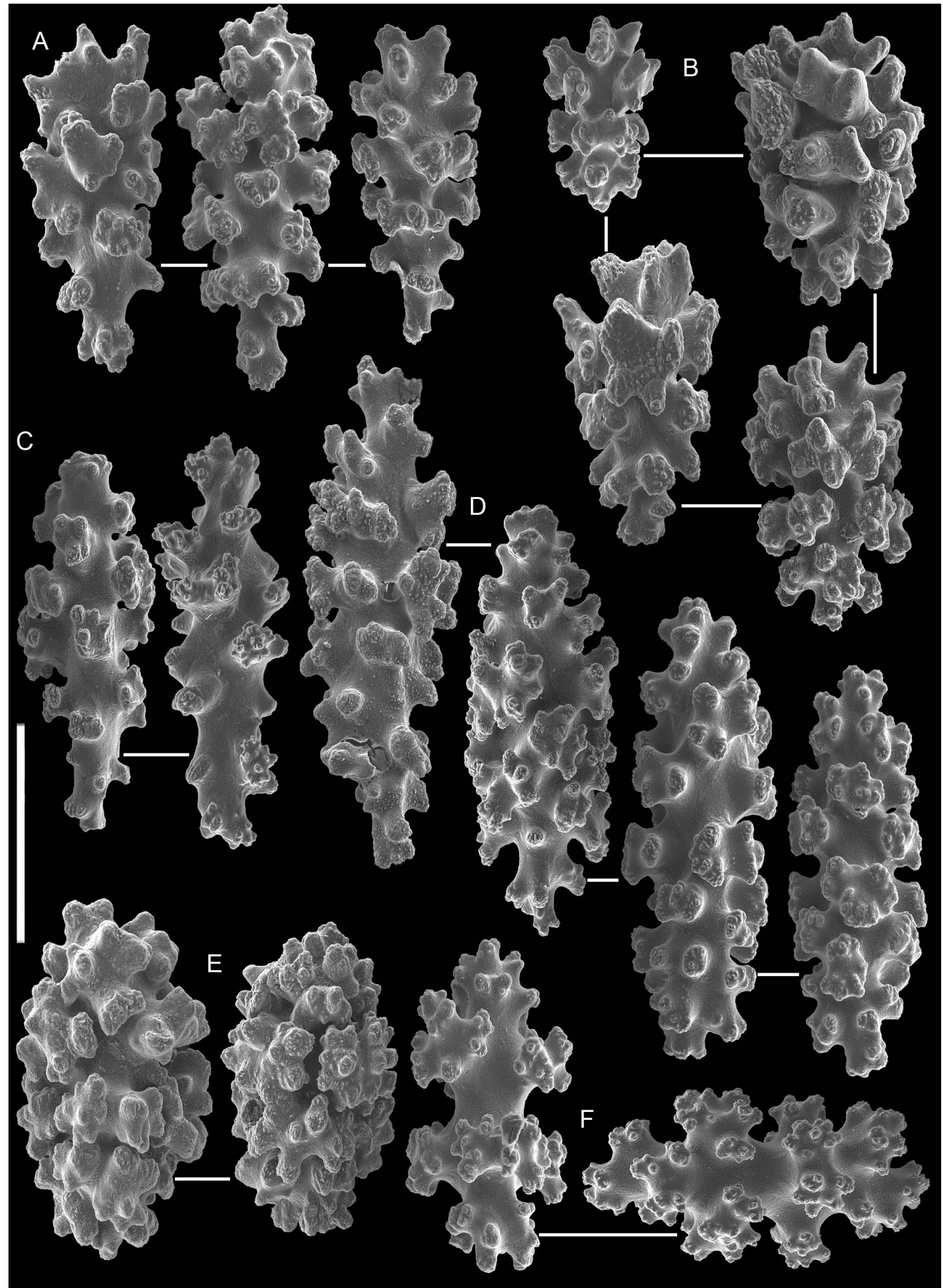

Fig. 3. Calcigorgia herba sp. nov., holotype MIMB 20744, sclerites from the polyp body wall. A. Warty clubs. B. Poorly developed clubs with leafy processes. C. Club-like spindles. D. Plump spindles with well-developed warts. E. Ovals. F. Capstans (8-radiate) with girdled warts. Scale bar $=0.1 \mathrm{~mm}$. 
and capstans, mostly $0.14-0.16 \mathrm{~mm}$, ornamented with girdled warts (Fig. 3F). Clubs, spindles and ovals abundant. Capstans not numerous.

Outer coenenchyme layer with numerous 8-radiate capstans, mostly $0.15-0.16 \mathrm{~mm}$ long (Fig. 4A). Massive capstans, up to $0.18 \mathrm{~mm}$ long, with very developed warts, transitional to ovals, up to $0.18 \mathrm{~mm}$ long, bearing densely crowded processes (Fig. 4B). Internal layer of coenenchyme contains weakly calcified capstans, up to $0.15 \mathrm{~mm}$ long, of same shape as those in outer layer.

\section{Paratype and variations}

Paratype MIMB 20745 colony shape and size similar to holotype - $159 \mathrm{~mm}$ high and $9 \mathrm{~mm}$ wide (Fig. 1B). Polyp body wall smooth and cylindrical; tentacles folded over the polyp and partly retracted to the inside (Fig. 1G). Sclerites composition (Figs 5-7) coincides with that in holotype (Figs 2-4). The only difference is some greater calcification of sclerites in polyp body wall of paratype - its warty clubs (Fig. 6A) and poorly developed clubs (Fig. 6D) with more wide heads than those in holotype (Fig. 3A-B). Club-like spindles in paratype slightly longer - up to $0.25 \mathrm{~mm}$ in polyp tentacles (Fig. 6B) vs $0.23 \mathrm{~mm}$ in holotype (Fig. 2F). Short, poorly developed clubs and ovals longer in polyp body wall of

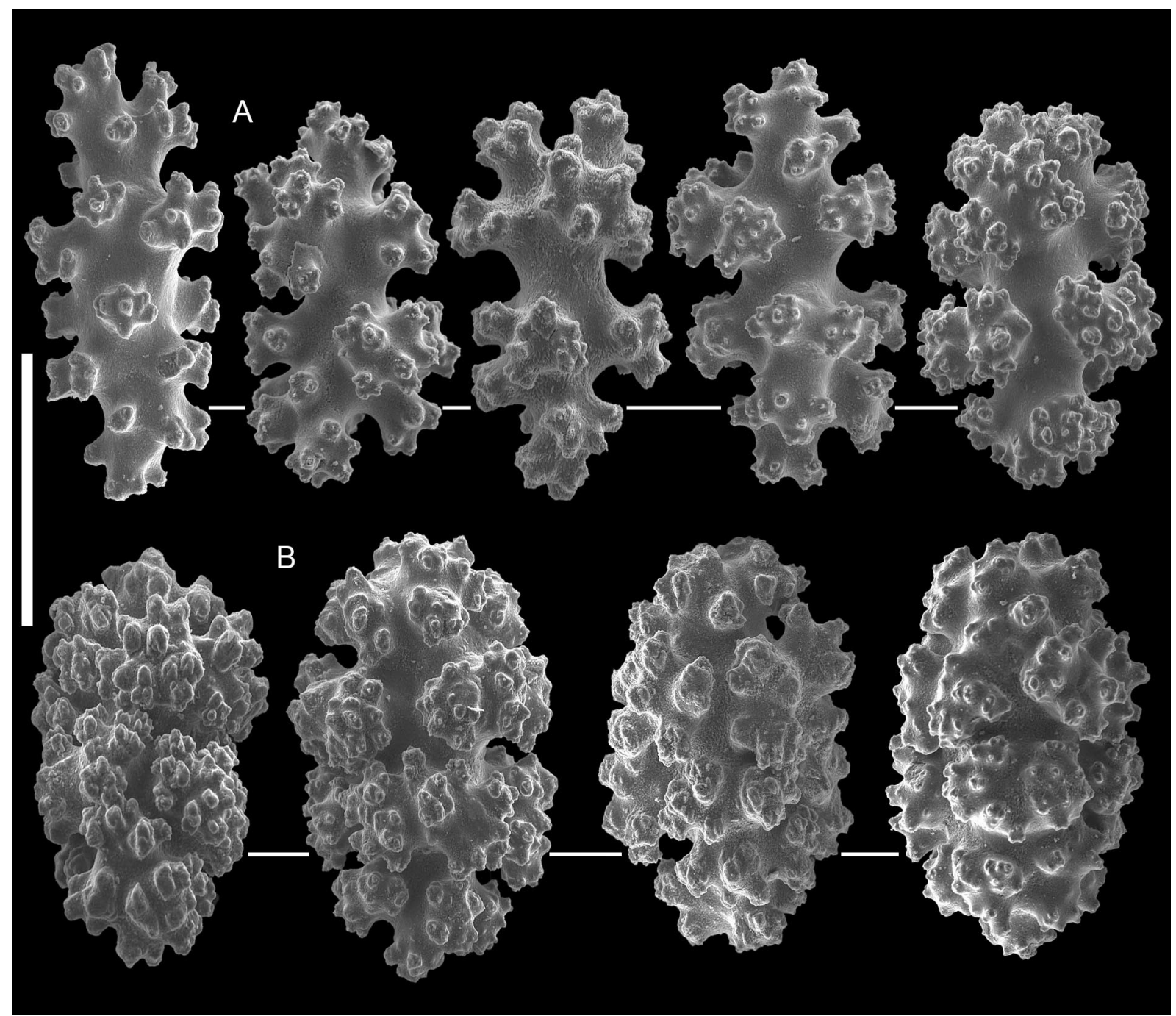

Fig. 4. Calcigorgia herba sp. nov., holotype MIMB 20744, sclerites from the coenenchyme. A. Well calcified capstans (8-radiate). B. Ovals. Scale bar $=0.1 \mathrm{~mm}$. 


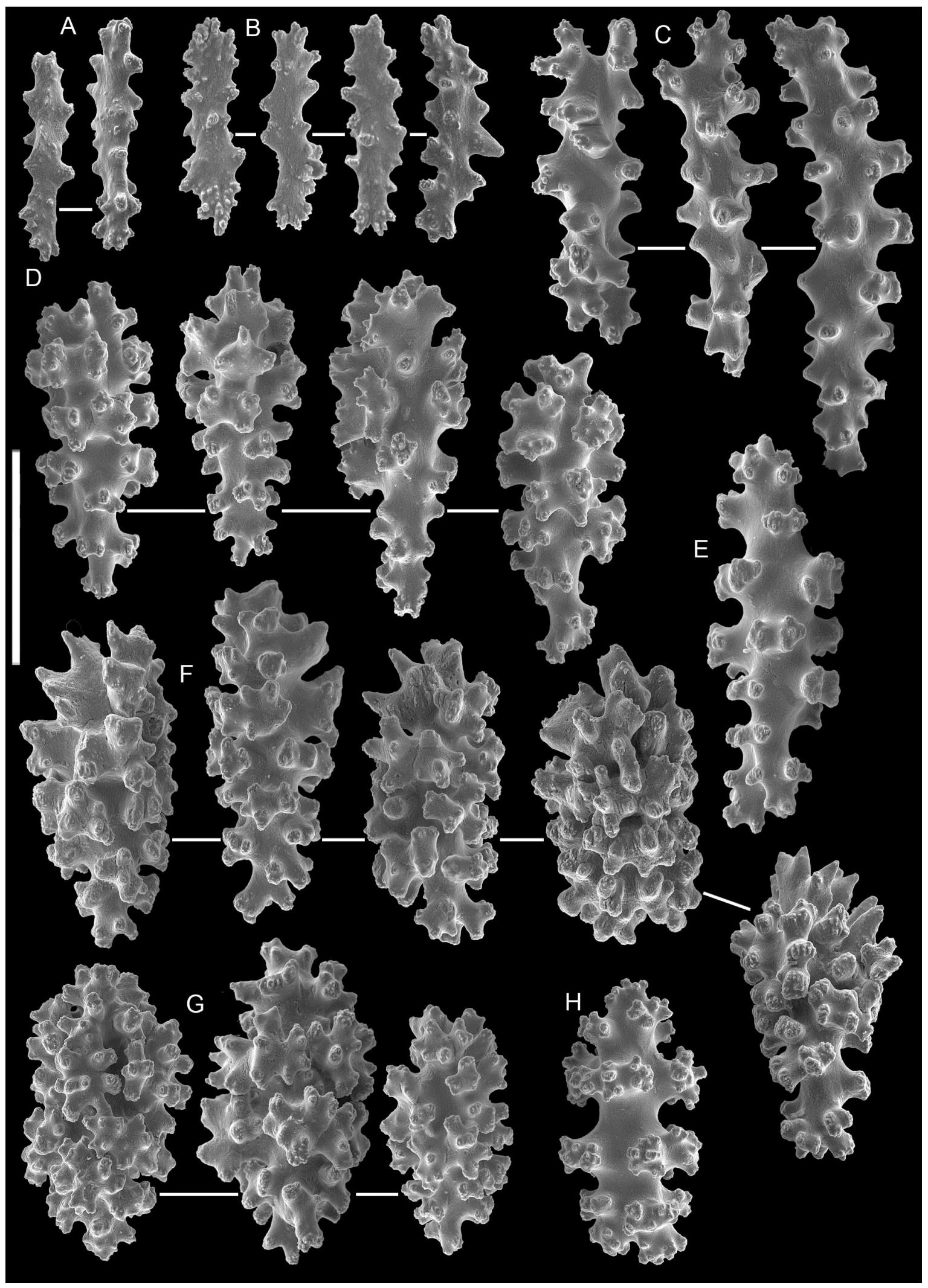

Fig. 5. Calcigorgia herba sp. nov., paratype MIMB 20745, sclerites from the tentacles of polyp. A. Modified clubs. B. Scales. C. Spindles. D. Warty clubs. E. Spindle. F. Poorly developed clubs with serrated processes. G. Ovals. H. Capstan (8-radiate). Scale bar $=0.1 \mathrm{~mm}$. 


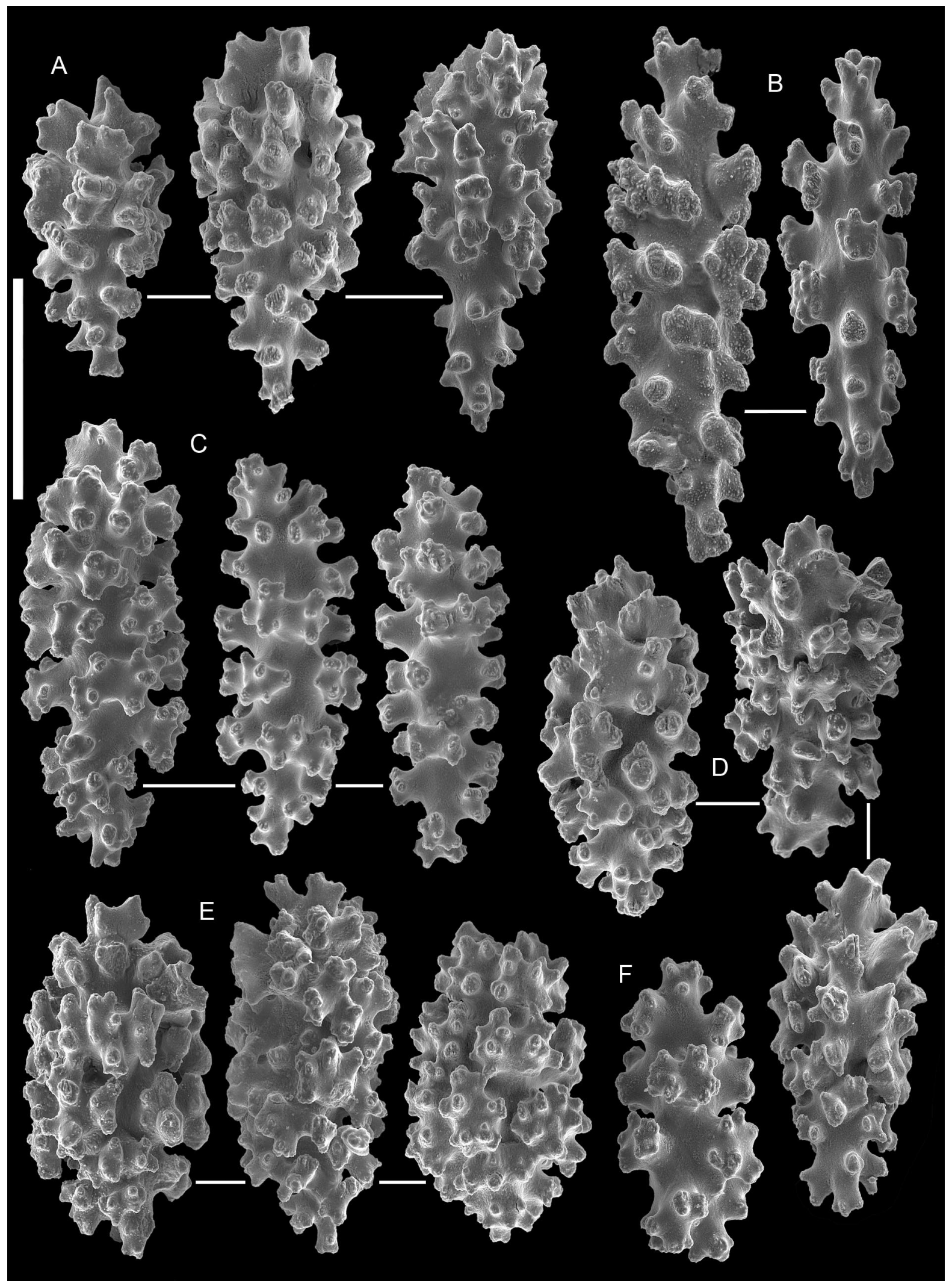

Fig. 6. Calcigorgia herba sp. nov., paratype MIMB 20745, sclerites from the polyp body wall. A. Warty clubs. B. Club-like spindles. C. Plump spindles with well-developed warts. D. Poorly developed clubs with serrated processes. E. Ovals. F. Capstan (8-radiate). Scale bar $=0.1 \mathrm{~mm}$. 
the paratype - up to $0.18 \mathrm{~mm}$ (Fig. 6D-E) vs $0.16 \mathrm{~mm}$ in holotype (Fig. 3B, E). Plump spindles of same size numerous in both paratype (Fig. 6C) and holotype (Fig. 3D). The coenenchyme of the paratype double-layered as in holotype, with 8-radiate capstans, up to $0.16 \mathrm{~mm}$ long (Fig. 7A), and well calcified ovals up to $0.18 \mathrm{~mm}$ long (Fig. $7 \mathrm{~B}$ ).

\section{Colour}

In alcohol-preserved material: polyps and coenenchyme creamy; colony axis black or deeply brown, sclerites colourless.

\section{Remarks}

The most obvious distinctive characters of $C$. herba sp. nov., differing from characters of other known members of the genus, are the shape of colony (with slender smooth stem and polyps crowded in the terminal part of the colony) and the presence of two different types of clubs among the sclerites. One

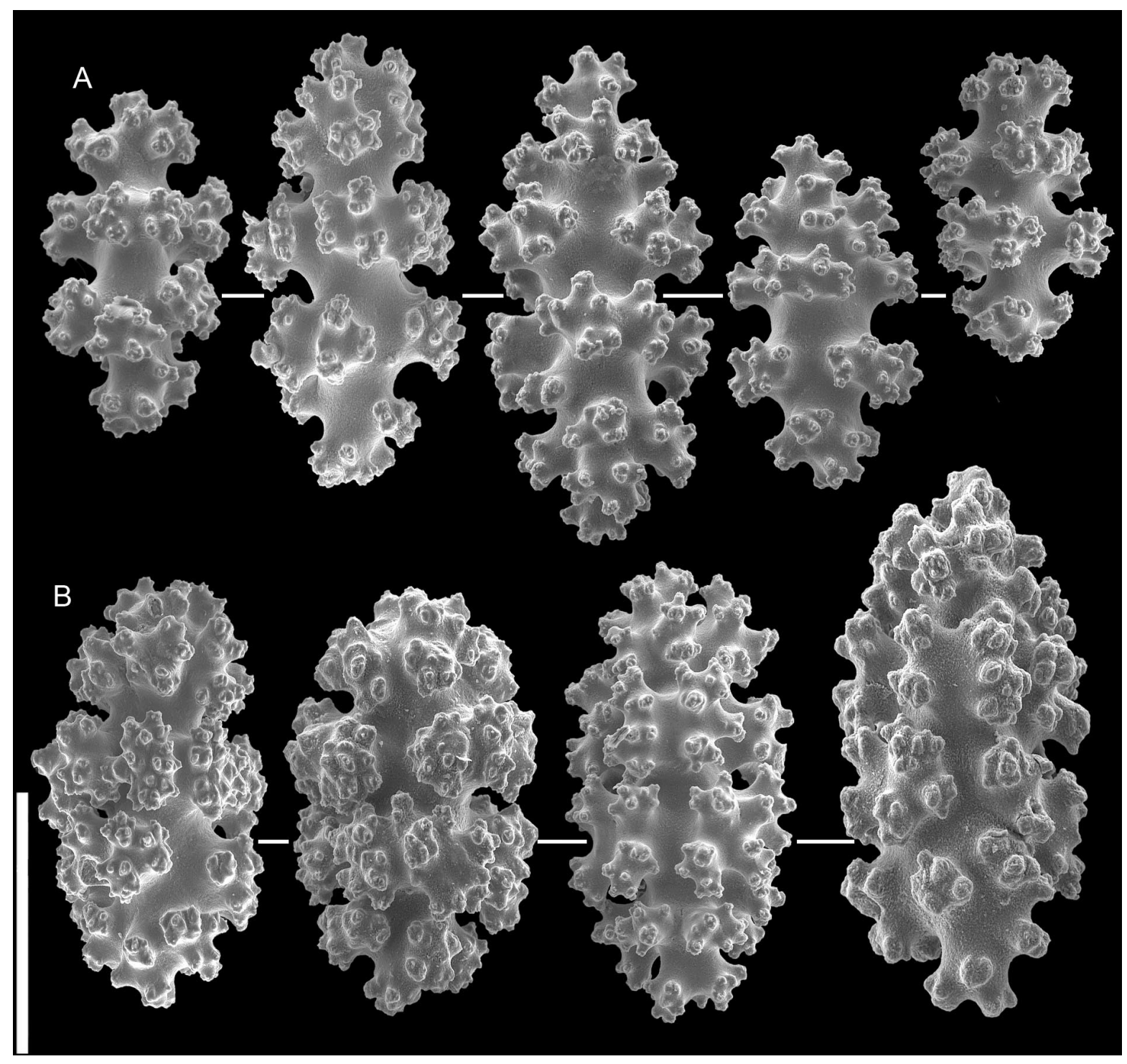

Fig. 7. Calcigorgia herba sp. nov., paratype MIMB 20745, sclerites from the coenenchyme. A. Well calcified capstans (8-radiate). B. Ovals. Scale bar $=0.1 \mathrm{~mm}$. 


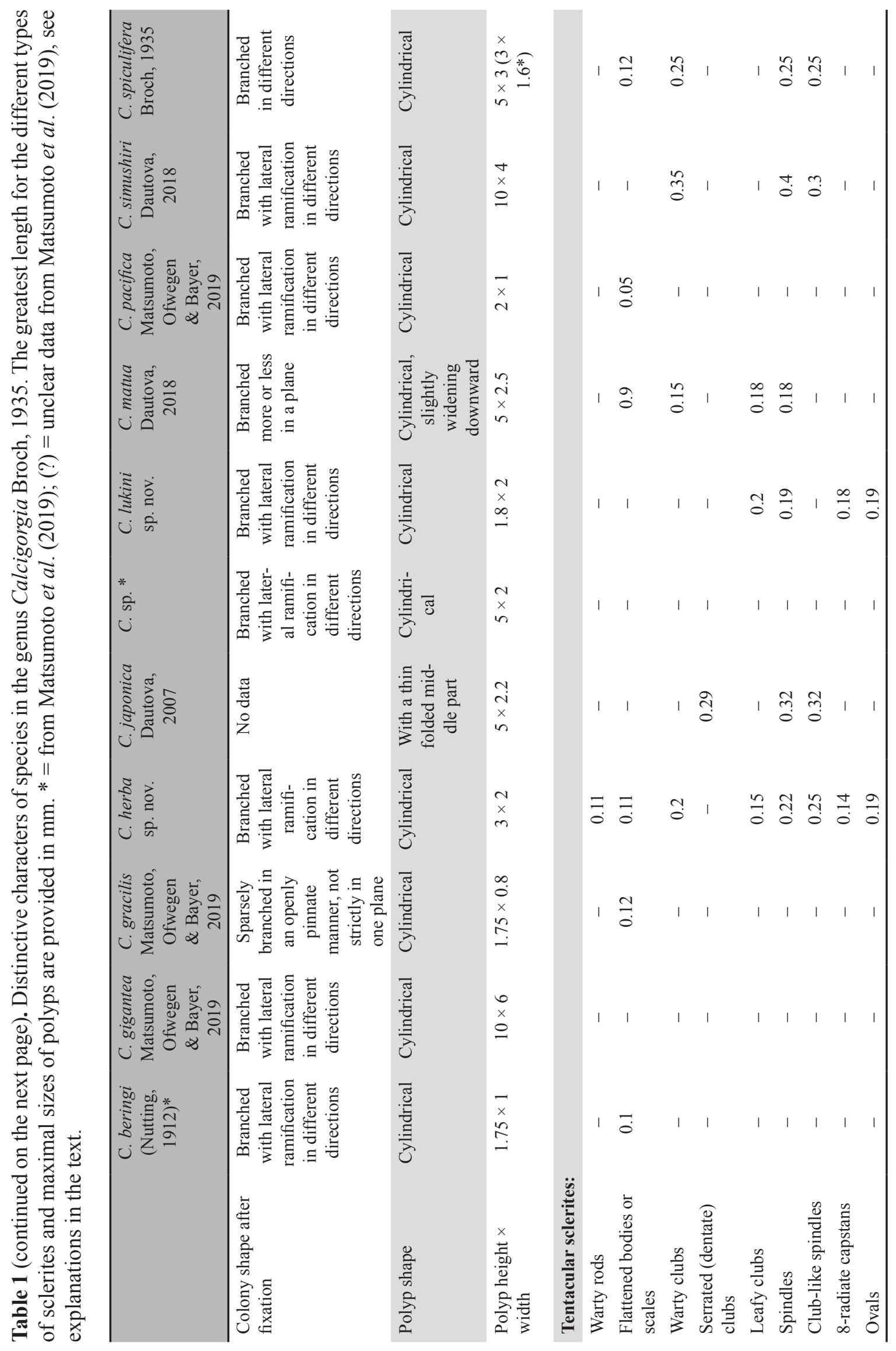




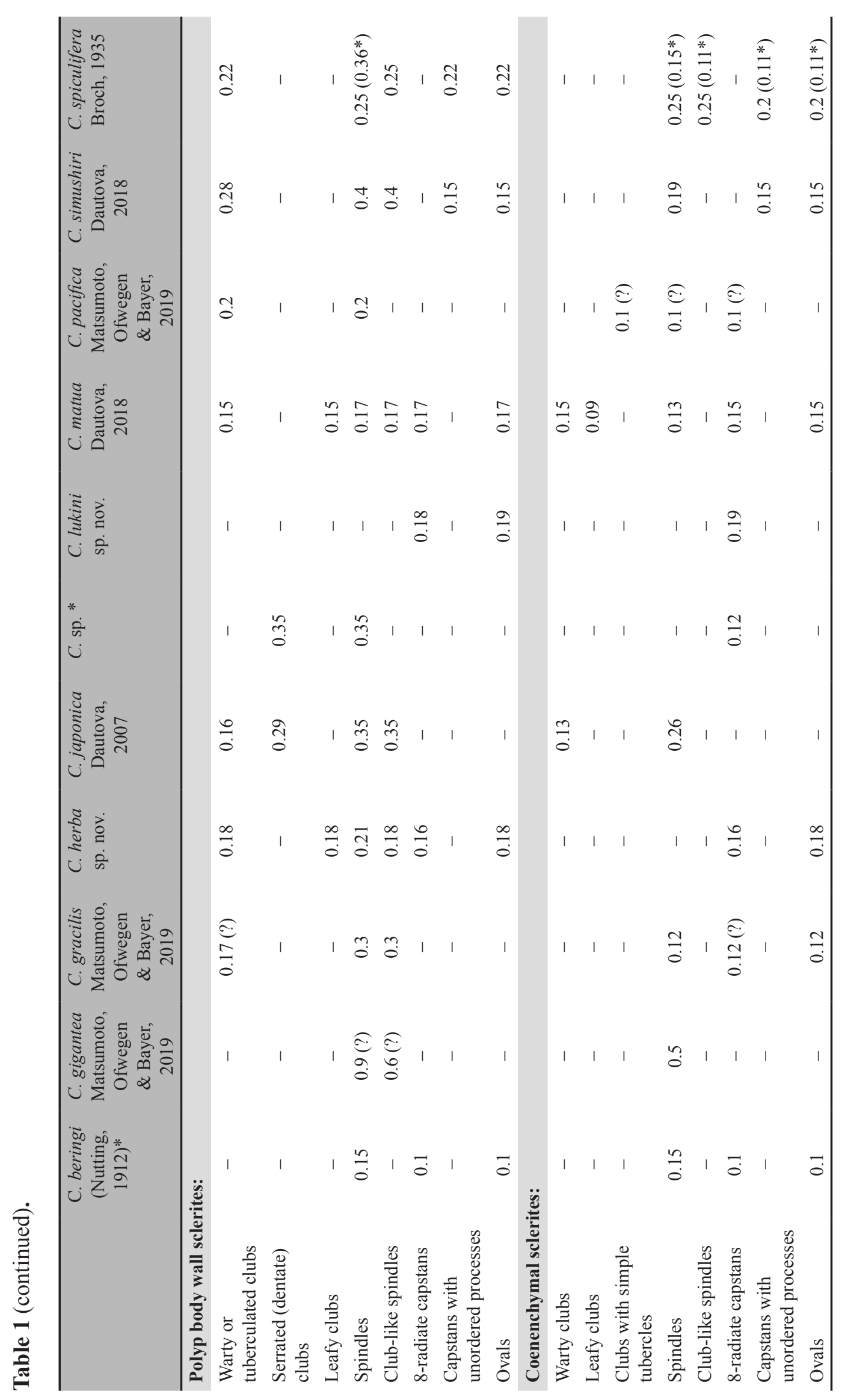


of these types, the poorly developed clubs with notched leafy processes on their heads and short warty handle, has not been described before in any of the known species of the genus (Figs 2E, 3B, 5F, 6D, Table 1). Moreover, only C. herba sp. nov. has warty rods along with scales in the tentacles (Fig. 2A, Table 1) and two types of sclerites in the coenenchyme - 8-radiate capstans and ovals (Figs 4A-B, 7AB, Table 1).

C. herba sp. nov. coincides with C. lukini sp. nov. having ovals and capstans in the tentacles but the last has no clubs in the polyp body (Table 1). The composition of the sclerites in the polyp body wall of $C$. herba sp. nov. coincides with that of C. spiculifera, C. matua and C. simushiri as all these species have warty clubs, spindles, capstans and ovals in that part of polyp (Table 1). However, only C. herba sp. nov. has poorly developed leafy clubs with thick warty handles in that part of polyp (Figs 3B, 6D, Table 1). Furthermore, C. simushiri has long-handled clubs that are missing in $C$. herba sp. nov. (Table 1). Thus, the morphology of polyps and composition and size of sclerites in the polyp and coenenchyme distinguish $C$. herba sp. nov. from all previously described representatives of the genus.

\title{
Distribution
}

This species is known for certain from the Kurile Islands, Sea of Okhotsk, Northwestern Pacific, between 75 and $200 \mathrm{~m}$ depth.

\author{
Calcigorgia lukini sp. nov. \\ urn:lsid:zoobank.org:act:C2373F6E-0EA5-4E4B-804D-772AF1DB0738
}

Figs $8-12$, Table 1

\section{Diagnosis}

Calcigorgia colonies scantly branched in several planes, with short smooth stem. Polyps remote from each other, arranged irregularly on surface of the branch, in alcohol-preserved material up to $1.8 \mathrm{~mm}$ high and up to $1.8 \mathrm{~mm}$ wide. Body walls of polyps with smooth surface; lower parts of polyps slightly widened. Polyp tentacles with warty spindles, poorly developed clubs with leafy processes on head, ovals and 8-radiate capstans. Polyp body walls with 8-radiate capstans and ovals. Both layers of coenenchyme with 8-radiate capstans; outer layer may contain ovals.

\section{Etymology}

The specific epithet is given in honor of Dr Vladimir Lukin, enthusiastic researcher of marine biodiversity in the National Scientific Centre of Marine Biology FEB RAS, who made a great collection of invertebrates in the Sea of Okhotsk in the 1980s.

\section{Material examined}

\section{Holotype}

SEA OF OKHOTSK - Kurile Islands $\bullet 95 \times 59 \mathrm{~mm}$; Iturup Is.; expedition of PFRC and ZIN RAS on

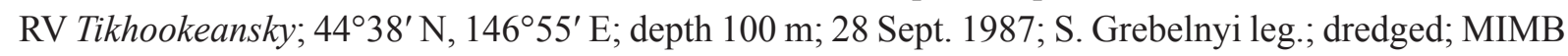
20710.

\section{Paratype}

SEA OF OKHOTSK - Kurile Islands • $112 \times 44 \mathrm{~mm}$; Iturup Is.; expedition of PFRC and ZIN RAS on

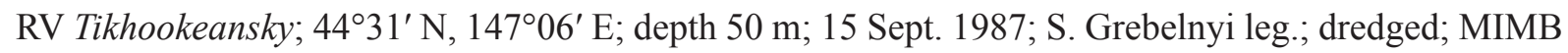
20712. 


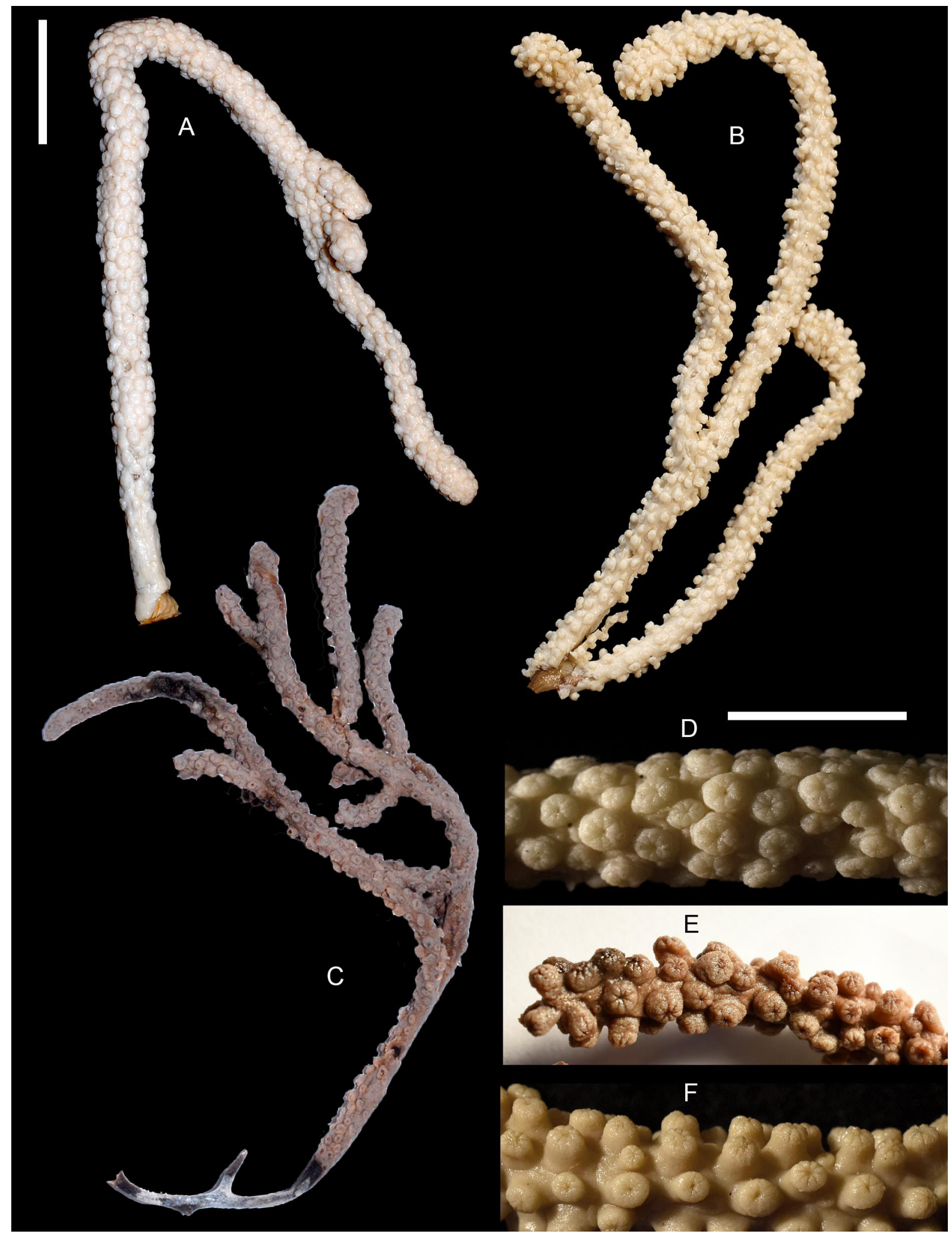

Fig. 8. Calcigorgia lukini sp. nov. A. Holotype MIMB 20710, Kurile Islands, Sea of Okhotsk. B. Paratype MIMB 20712, Kurile Islands, Sea of Okhotsk. C. Specimen from the Urup Is., Kurile Islands, Sea of Okhotsk, MIMB 20691. D. Side polyps, holotype MIMB 20710. E. Terminal polyps, MIMB 20691. F. Side polyps, MIMB 20743. Scale bars: A-C = $20 \mathrm{~mm}, \mathrm{D}-\mathrm{F}=10 \mathrm{~mm}$. 


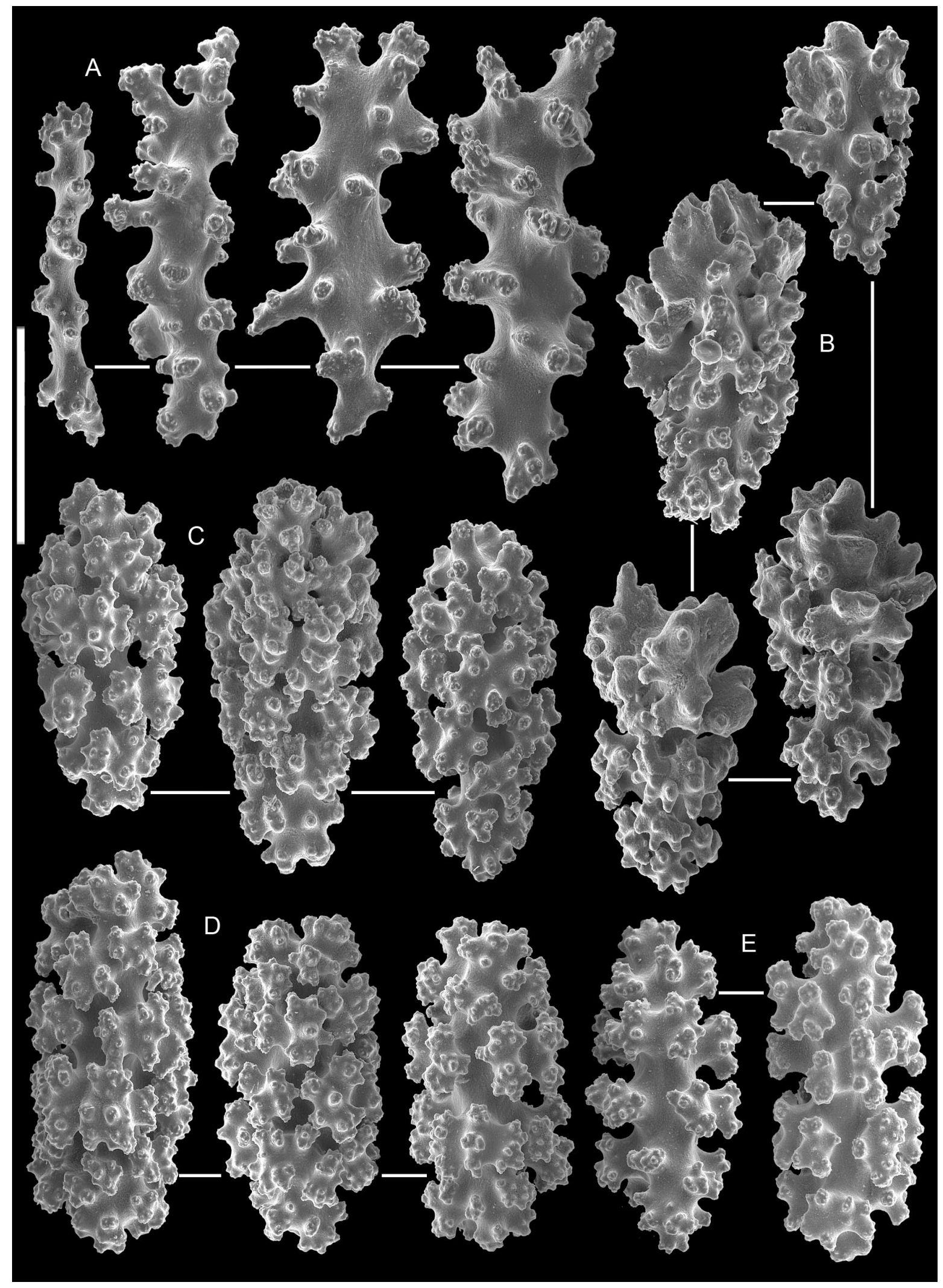

Fig. 9. Calcigorgia lukini sp. nov., holotype MIMB 20710, sclerites from the tentacles of polyp. A. Warty spindles. B. Clubs with leafy processes. C. Asymmetrical ovals. D. Symmetrical ovals. E. Capstans (8-radiate). Scale bar $=0.1 \mathrm{~mm}$. 


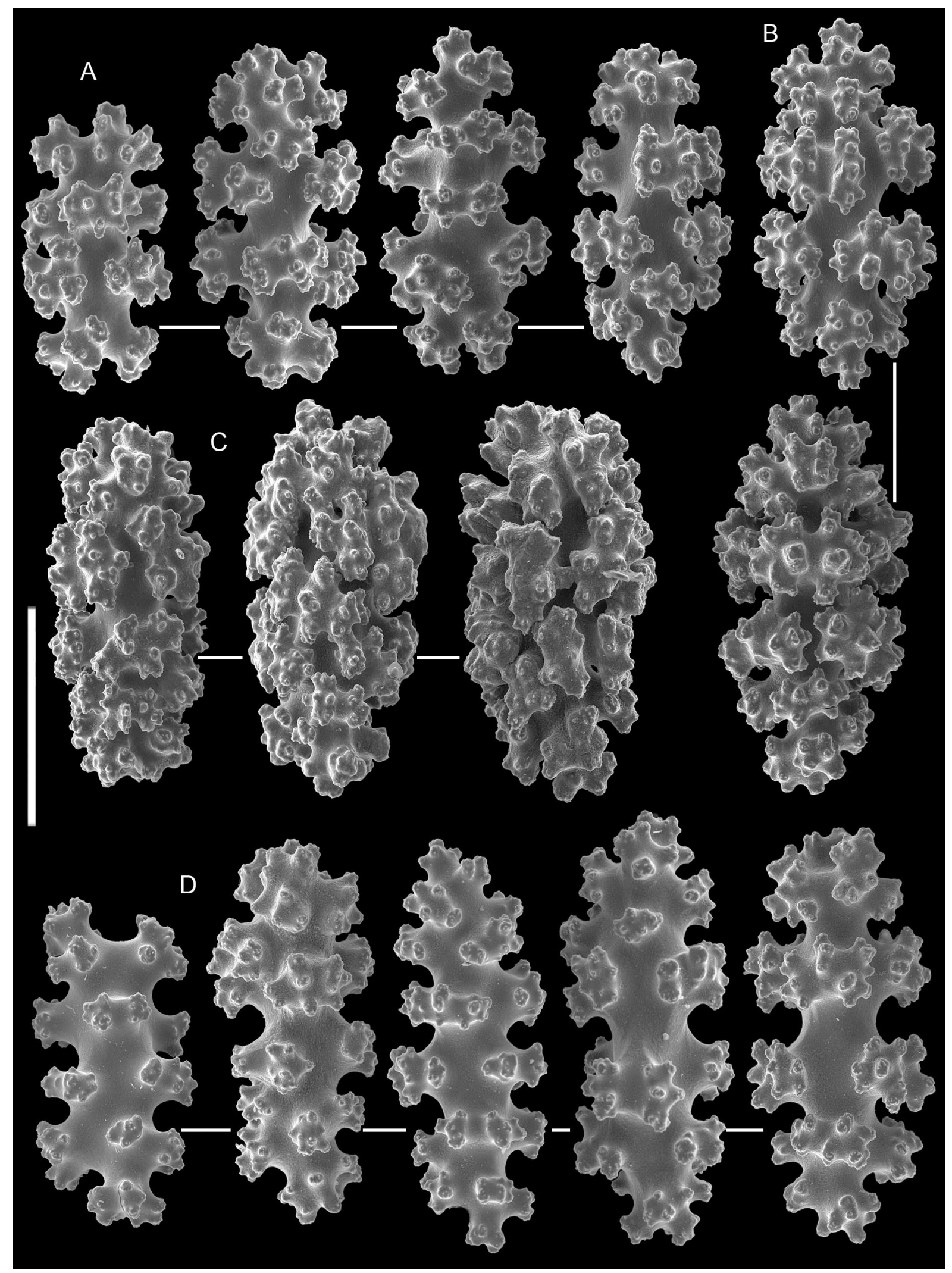

Fig. 10. Calcigorgia lukini sp. nov., holotype MIMB 20710, sclerites. A. Capstans from polyp body wall. B. Well calcified capstans from polyp body wall. C. Ovals from polyp body wall. D. Capstans (8-radiate) from the coenenchyme. Scale bar $=0.1 \mathrm{~mm}$. 


\section{Additional material}

SEA OF OKHOTSK • 1 specimen; Urup Is., Kurile Islands; $45^{\circ} 54^{\prime} \mathrm{N}, 149^{\circ} 59^{\prime} \mathrm{E}$; depth $60 \mathrm{~m}$; 12 Oct. 1973; Artemov leg.; dredged; MIMB 20691 • 1 specimen; Shelikhov Bay; cruise of RV Akademik Oparin; $60^{\circ} 02^{\prime}$ N, $158^{\circ} 24^{\prime}$ E; depth 60 m; 19 Aug. 2008; Nikolay Selin leg.; dredged; MIMB 20743.

\section{Description}

\section{Holotype}

Holotype alcohol-preserved colony $95 \mathrm{~mm}$ high and $59 \mathrm{~mm}$ wide, scantily branched (Fig. 8A). Side branches flexible, placed irregularly. Polyps up to $1.5 \mathrm{~mm}$ high and $2 \mathrm{~mm}$ wide, disposed irregularly at distances of 1-2 $\mathrm{mm}$ from each other. Tentacles folded over polyp and partly retracted to inside; polyp body smooth and cylindrical in shape (Fig. 8D).

Coenenchyme $0.8 \mathrm{~mm}$ thick, in two layers; a $0.6 \mathrm{~mm}$ thick outer layer, with smooth surface; a very thin inner layer, semi-transparent and longitudinally ridged. Axis with concentric layers without any visible mineralization. The axial canal present, but very narrow and hardly visible in the tip of the branches.

Tentacles with warty spindles, poorly developed clubs with a warty handle and leafy processes on head, ovals and capstans. Warty spindles, of irregular shape, branched, mainly $0.17-0.19 \mathrm{~mm}$ long, covered by granulated warts (Fig. 9A). Clubs mainly $0.12-0.19 \mathrm{~mm}$ long, sometimes up to $0.20 \mathrm{~mm}$, with a plump head, consisting of several leafy processes (Fig. 9B). Short handle straight, thick and blunt, densely ornamented with small warts. Some longer clubs, up to $0.2 \mathrm{~mm}$, with poorly developed leafy processes on head and very thick handle, are transitional to asymmetrical warty ovals (Fig. 9C). These ovals mainly up to $0.19 \mathrm{~mm}$ long, ornamented with small crowded warts tending to be conjunct (Fig. 9C). Symmetrical ovals well calcified, usually up to $0.18-0.19 \mathrm{~mm}$ long (Fig. 9D). Capstans mostly up to $0.18 \mathrm{~mm}$ long (Fig. 9E). These are well-calcified 8-radiate sclerites with two girdles of warts and plump terminal processes.

Numerous capstans (8-radiate) in body wall of polyps, mainly $0.16-0.18 \mathrm{~mm}$ long, with plump terminal warts (Fig. 10A). Well calcified capstans, up to $0.18 \mathrm{~mm}$ (Fig. 10B), transitional to warty ovals. Ovals, mostly $0.16-0.19 \mathrm{~mm}$ long, ornamented with warts tending to be conjunct (Fig. 10C).

Both layers of coenenchyme contain capstans, mostly 0.16-0.19 mm long (Fig. 10D). These wellcalcified 8-radiate sclerites with two girdles of warts and plump terminal processes. Some capstans, up to $0.13 \mathrm{~mm}$ long, less calcified, but with well-formed and girdled warts.

\section{Paratype and variations}

Paratype MIMB 20712 colony shape and size similar to the holotype - $112 \mathrm{~mm}$ high and $44 \mathrm{~mm}$ wide (Fig. 8B). Polyps up to $1.6 \mathrm{~mm}$ high and $2 \mathrm{~mm}$ wide, disposed irregularly at distances of $1-2 \mathrm{~mm}$ from each other. Sclerites composition (Figs 11-12) coincides with that in the holotype (Figs 9-10). The only difference is smaller size of ovals and capstans in the polyp body wall and the coenenchyme of the paratype. Paratype's ovals shorter in polyp body wall - these mostly up to $0.16 \mathrm{~mm}$ long (Fig. 11C-D) vs up to $0.19 \mathrm{~mm}$ in the holotype (Figs $9 \mathrm{C}-\mathrm{D}, 10 \mathrm{C}$ ). Capstans in coenenchyme of the paratype mostly up to $0.15 \mathrm{~mm}$ long (Fig. 11F) vs up to $0.19 \mathrm{~mm}$ in the holotype (Fig. 10D).

\section{Colour}

In alcohol-preserved material: the polyps and coenenchyme creamy or light-brown; the colony axis black or deeply brown; sclerites colourless. 


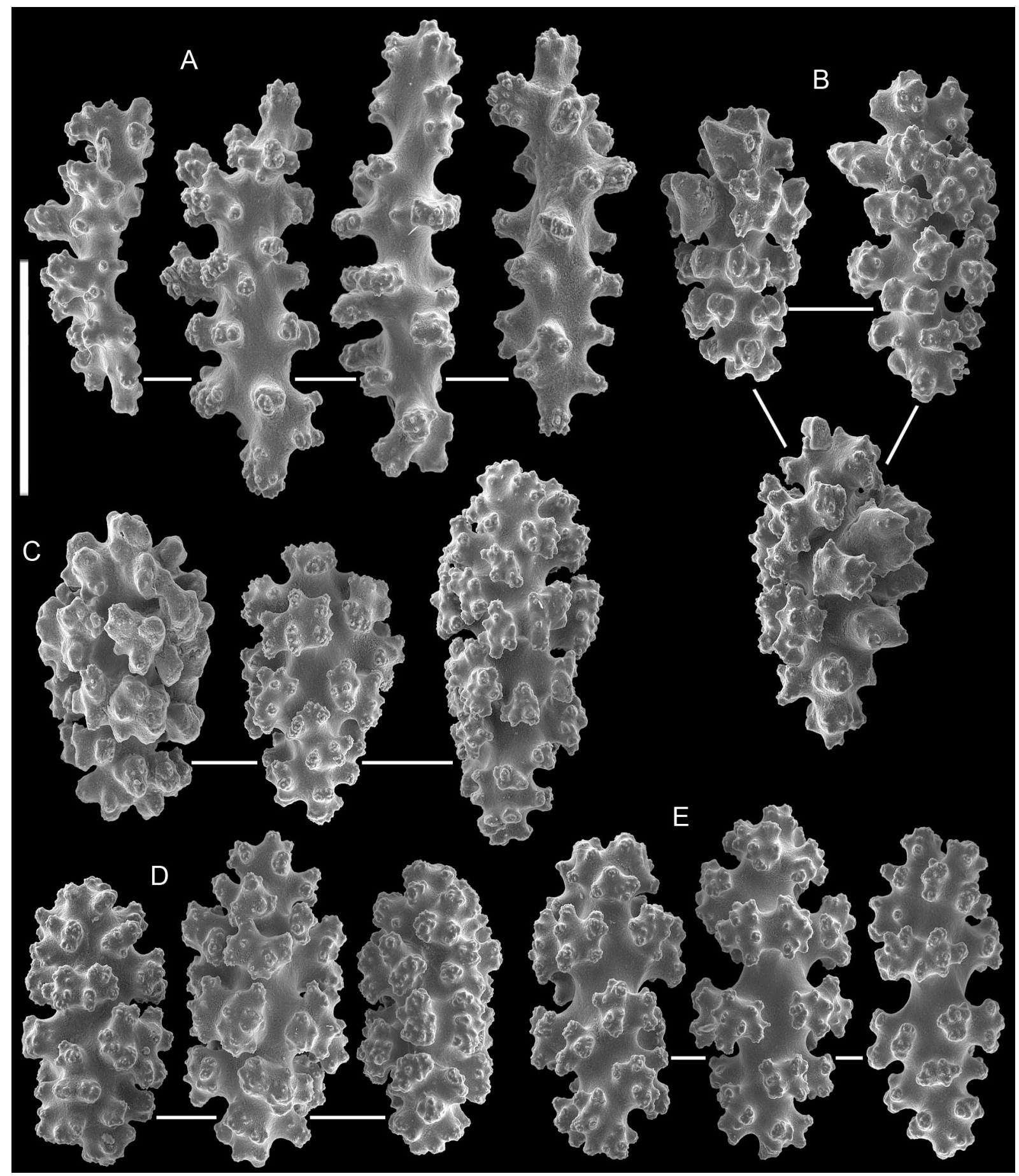

Fig. 11. Calcigorgia lukini sp. nov., paratype MIMB 20712, sclerites from the tentacles. A. Warty spindles from the tentacles. B. Clubs with leafy processes. C. Asymmetrical ovals. D. Symmetrical ovals. E. Capstans (8-radiate). Scale bar $=0.1 \mathrm{~mm}$. 


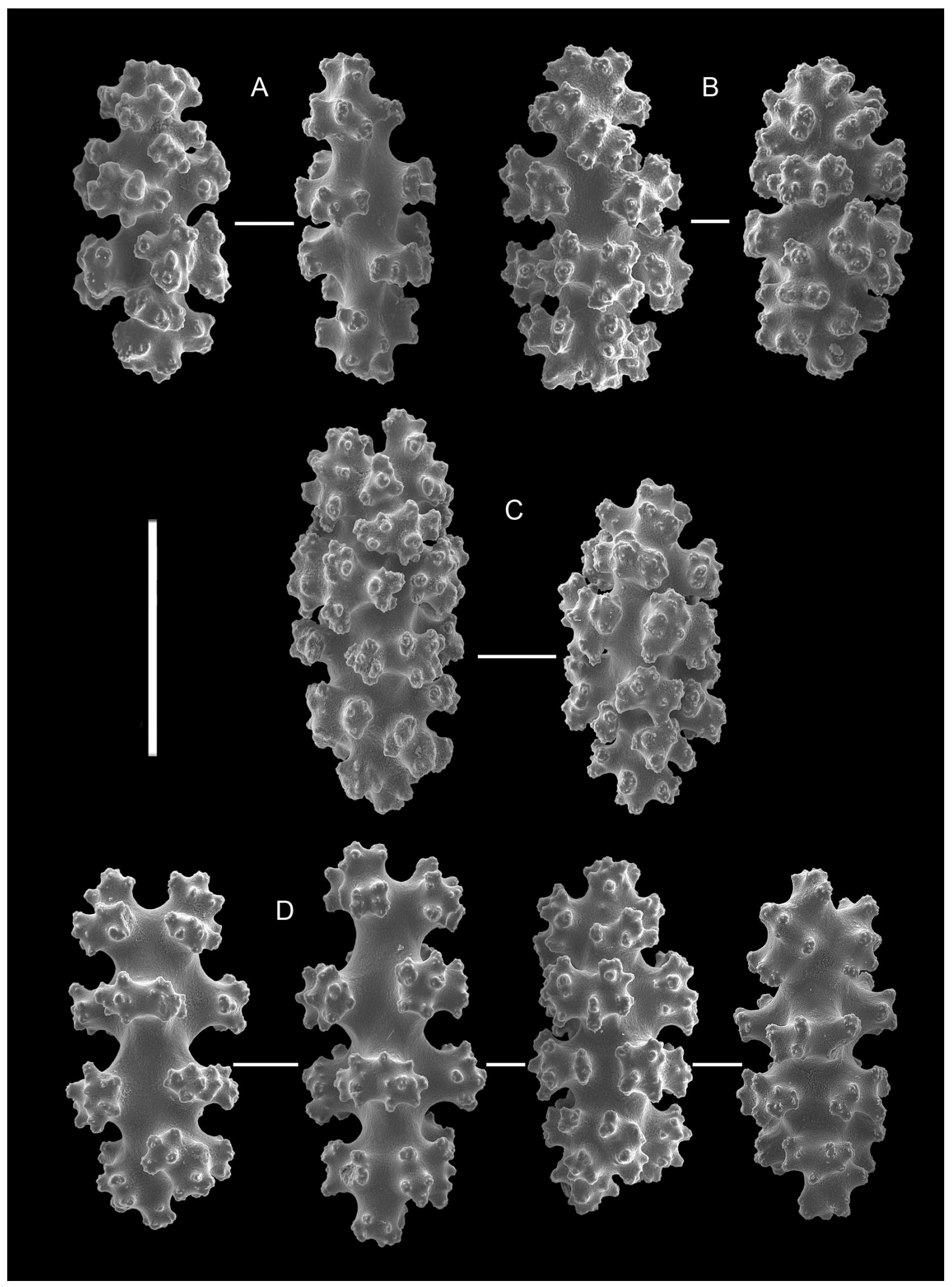

Fig. 12. Calcigorgia lukini sp. nov., paratype MIMB 20712, sclerites A. Capstans from polyp body wall. B. Well calcified capstans (8-radiate) from polyp body wall. C. Ovals from polyp body wall. D. Capstans (8-radiate) from the coenenchyme. Scale bar $=0.1 \mathrm{~mm}$. 


\section{Remarks}

Calcigorgia lukini sp. nov. presents a range of characters differing from other known species of the genus.

Polyps of C. lukini sp. nov. are somewhat smaller (with a low polyp body wall in fixed specimens, Fig. 8D-F), than those of other representatives of the genus. A scant set of the sclerite types (spindles, clubs, 8-radiate capstans and ovals) clearly differentiate this species (Table 1). Tentacles of C. lukini sp. nov. contain neither the warty clubs nor the flattened bodies that occur in other representatives of the genus (Table 1).

Calcigorgia lukini sp. nov. coincides with $C$. herba sp. nov. in the presence of poorly developed leafy clubs (Figs 2D, 3B, 5F, 6D, 9B, 11B) and spindles with tall and asymmetrically developed processes in polyp tentacles (Figs 2E, 5C, 9A, 11A). However, C. lukini sp. nov. differs from C. herba sp. nov. in the absence of warty rods, scales and warty clubs in tentacles and, also, in the absence of clubs in the polyp body wall (Table 1). Finally, C. lukini sp. nov. is the only species in the genus containing only capstans and ovals in the polyp body wall and a single sclerite type in the coenenchyme - 8-radiate capstans (Table 1). C. gigantea Matsumoto, Ofwegen \& Bayer, 2019 also contains a single sclerite type in the coenenchyme, but these are spindles (Matsumoto et al. 2019).

\section{Distribution}

This species is known only from the Kurile Islands and Shelikhov Bay, Sea of Okhotsk, Northwestern Pacific, between 50 and $100 \mathrm{~m}$ depth.

\section{Discussion}

Corals are among the most widespread and important groups of marine macro-benthic animals, but the diversity and distribution of octocorals in deep-water areas of the Pacific have been studied unevenly (Roberts et al. 2006; Pérez et al. 2016). Within the temperate Northwest Pacific, the majority of the 30 recorded deep-water Octocorallia families have been reported only from a few areas where taxonomists have long been active - the Pacific part of Japanese waters (29 families) and the Northwest coast of America (23 families) (Wing \& Barnard 2004; Heifetz et al. 2005; Herrera et al. 2010; Cairns \& Hourigan 2017; Parrish et al. 2017; Stone \& Cairns, 2017). Limited data exist for deep-sea octocorals from Far East seas, such as the western Bering Sea or the Sea of Okhotsk. The rich region of the Sea of Okhotsk (the area around the Kurile Islands, in particular) was beyond the scope of research on deepwater corals, and its Octocorallia fauna and taxonomy remained poorly studied (Dautova 2018a). It was 72 years after Calcigorgia spiculifera Broch, 1935, type species of the genus, was described from the Sea of Okhotsk that three additional species were recorded from the Sea of Japan and the area of the Kurile Islands (Dautova 2007, 2018b). Later, four new species were added to the genus from the area of the Aleutian Islands and Pacific coasts of the Japan (Matsumoto et al. 2019). One of these species was initially described as Leptogorgia beringi by Nutting (1912). Matsumoto et al. (2019) have redescribed it as Calcigorgia beringi (Nutting, 1912) based on an unpublished manuscript of the late Dr F.M. Bayer (USNM: National Museum of Natural History, Smithsonian Institution, Washington D.C., USA) in which the author proposed that re-description, and on the SEM images of USNM 30044, the holotype of C. beringi (see Matsumoto et al. 2019: 1).

In the present contribution, the taxonomic importance of the following characters is confirmed for the differentiation of the considered valid species in this genus: shape and size of polyps, colony branching pattern and distribution of polyps along the branches, and size and distribution of sclerites in the different parts of the colony. Clubs and spindles of different sizes and shapes and their distribution on the coral seem to be the most useful characters for distinguishing species of Calcigorgia, whereas 
8-radiate capstans and ovals differ only in their length (Table. 1). On the other hand, new data on Calcigorgia sclerites presented here show that distribution of capstans and ovals in a colony also help to distinguish the new species. For example, $C$. herba sp. nov. and $C$. lukini sp. nov. are the only species that have capstans and ovals in the tentacles (Figs 2H, 5G, 9D, Table 1). However, the ovals from the coenenchyme of Calcigorgia species should be used with caution for taxonomy in the genus, because these could be derived from the capstans due to the very intense calcification process in the coral and may thus be absent otherwise.

Considering the above, the genus Calcigorgia Broch, 1935 includes at present time the following species: C. beringi (Nutting, 1912), C. gigantea Matsumoto, Ofwegen \& Bayer, 2019, C. gracilis Matsumoto, Ofwegen \& Bayer, 2019, C. herba sp. nov., C. japonica Dautova, 2007, C. lukini sp. nov., C. matua Dautova, 2018, C. pacifica Matsumoto, Ofwegen \& Bayer, 2019, C. simushiri Dautova, 2018, C. spiculifera Broch, 1935 (type species), and Calcigorgia sp. from Matsumoto et al. (2019). The validity of $C$. gigantea, $C$. gracilis and C. pacifica is beyond doubt despite numerous mistakes and ambiguity in the descriptions of these species. For example, Matsumoto et al. (2019: 18) noted "Tentacles with a few scales, up to $0.05 \mathrm{~mm}$ long, with a few simple tubercles (Figure 15a)" in the C. pacifica description.

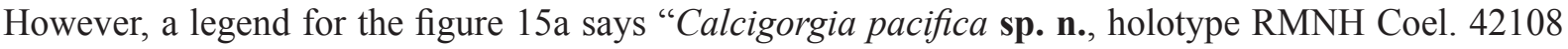
a undeveloped spindles" (Matsumoto et al. 2019: 20). That figure, in fact, shows small scales; so these are designated in Table 1 of the present paper. Furthermore, the authors did not list the club-like spindles neither in the text nor in the legend for their figure 15 concerning sclerites of the C. pacifica holotype. Nonetheless, some sclerites on their figure $15 b-c$ resemble club-like spindles, which are noted in Table 1 of the present paper. In the description of $C$. gracilis, these authors mentioned clubs in the polyp body but did not refer to any figures. These clubs are also mentioned in the caption for the SEM images of the sclerites of the C. gracilis holotype (Matsumoto et al. 2019: 10, fig. 7b). Unfortunately, images of sclerites in their figure 7 are neither connected nor circled by any auxiliary line (the same goes for the rest in that paper). This makes it difficult to understand which sclerites are marked with the letter "b". Some sclerites depicted to the right of the letter "b" in figure 7 of Matsumoto et al. (2019) resemble slender clubs, some others resemble spindles. As a result, information on distribution of sclerites in the different parts of the colony of $C$. gracilis and some other species in Matsumoto et al. (2019) is unclear (as marked in Table 1 of the present paper).

Designating the neotype of $C$. spiculifera Broch, 1935, Matsumoto et al. (2019) did not mention the presence of capstans and ovals in the polyps, the sclerite types that were pointed out and depicted by Broch (1935: 23, fig. 14b; Table 1 of the present contribution). The synonymization of $C$. simushiri with $C$. spiculifera performed by Matsumoto et al. (2019) raises serious doubts. The authors noted out: "The sclerites shown by Dautova (2018: Figure 7-13) for C. simushiri hardly differ from C. spiculifera (see discussion). Therefore we here synonymize $C$. simushiri with $C$. spiculifera." This seems to be a misprinting, given that the authors completed this synonymization. Calcigorgia simushiri coincides with C. spiculifera only in terms of composition of sclerites while the sizes and shape of these sclerites clearly differ (Dautova 2018b: table 1). Thus, the clubs in C. simushiri are long-handled. The handles of the clubs and the spindles in C. simushiri bear conical hillocks inclined to ends of spindle (Dautova 2018b: 12, figs 7B-D, 8C, F, 9D, 11, 12C-D). Such kinds of clubs and spindles have never been documented in other Calcigorgia species. Furthermore, $C$. simushiri has two to three-times bigger polyps in comparison with those in C. spiculifera (Table 1 of the present contribution). However, Matsumoto et al. (2019:26) considered C. simushiri Dautova, 2018 as intraspecific variation of $C$. spiculifera based, in fact, only on size of spindles of $C$. spiculifera. Therefore, the synonymization of these two species is concluded wrong.

The description of C. japonica extended by Matsumoto et al. (2019) is also doubtful. The authors did not compare sclerites of the C. japonica holotype listed and depicted in the paper of Dautova (2007: 
302-304, fig. 3c-g) despite it being kept in the Zoological Institute RAS in St.-Petersburg, Russia, under the number ZIN 10706 (see Dautova 2007: 302); Matsumoto et al. (2019: 11-15, figs 9-12) instead depicted another specimen, ZIN 11678, from the same museum. The material described by them differs strongly from C. japonica Dautova, 2007 in: 1) no sclerites in the tentacles and warty clubs in the polyp, and 2) capstans present in the coenenchyme (Table 1 in present paper). Furthermore, the specimen ZIN 11678 has clubs with a distinct central wart on the heads that is unique in Calcigorgia (Matsumoto et al. 2019: fig. 11). Assuming the above, it should be validated as a new species of the genus (Calcigorgia sp.; Table 1 in present paper).

The new findings support the thesis that the genus Calcigorgia is more speciose than estimated in the past (Dautova 2018b). Additional work remains to be done on the genus, such as a molecular phylogenetic analysis. More material has to be obtained using modern trawling methods or remotedly operated vehicles, especially in the Sea of Okhotsk and around the Kurile Islands.

The geographic range of Calcigorgia remains to be updated and determined. The known range of each species has been restricted due to limited sampling. Only the type species, C. spiculifera, has been reported over a wide range from Alaska and the Aleutian Islands to the Sakhalin Island and the Kurile Islands (Broch 1935; Heifetz et al. 2005; Dautova 2007, 2008, 2011; Cairns \& Hourigan 2017; Matsumoto et

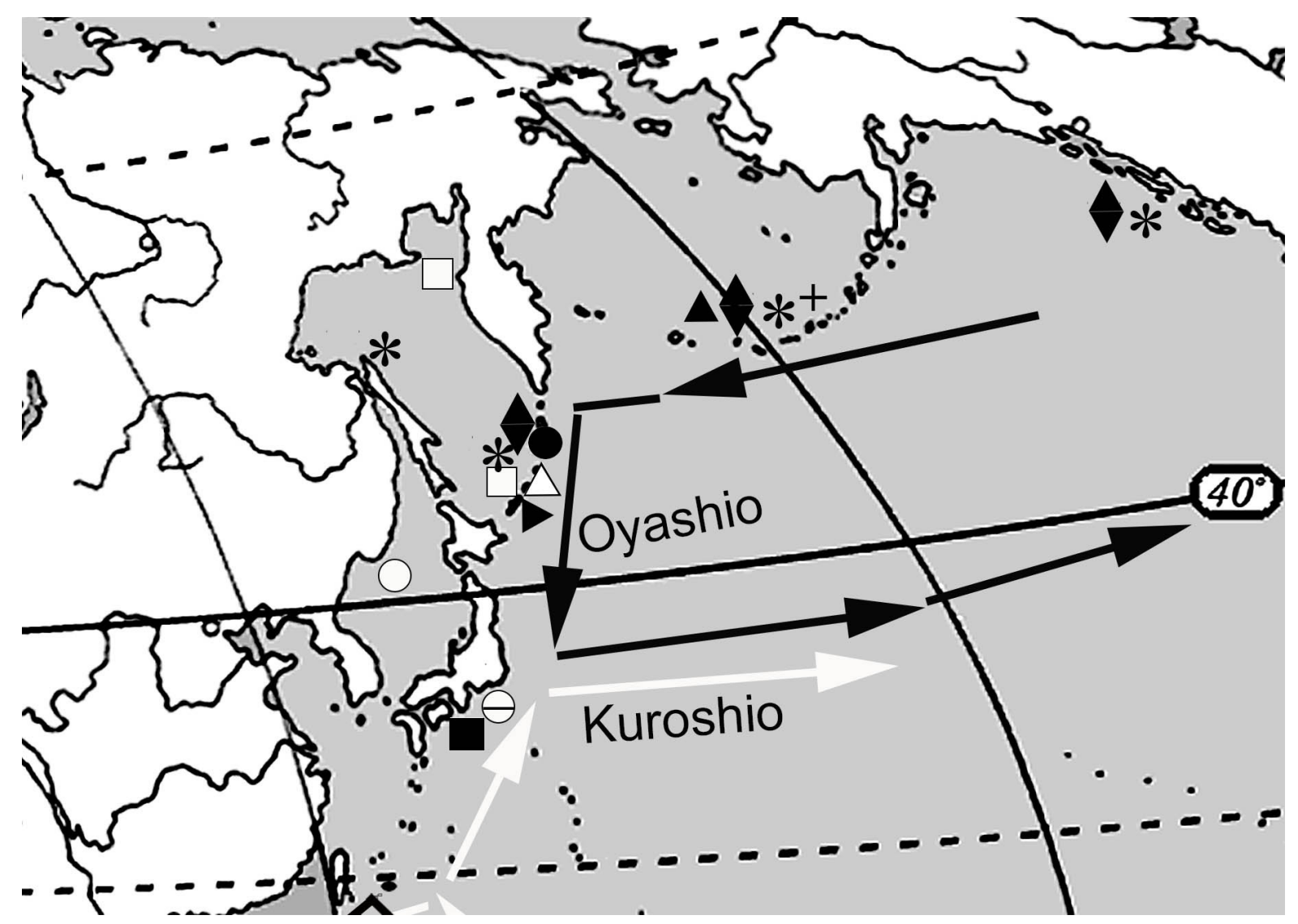

Fig. 13. Map of the distribution of the Calcigorgia gorgonians. The regions of Calcigorgia species collection (based on the literature and data in the present paper, see explanation in the text) are marked: $\checkmark=C$. beringi; $+=C$. gigantea; $\Theta=C$. gracilis; $\bullet=C$. herba sp. nov.; $\circ=C$. japonica $; \square=C$. lukini sp. nov.; $\Delta=C$. matua; $=C$. pacifica; $\boldsymbol{\Delta}=C$. simushiri; $*=C$. spiculifera $;=$ Calcigorgia sp. Black arrows indicate the direction of the Alaskan Stream and Oyashio Current; white arrows show the direction of the Kuroshio Current. 
al. 2019; Fig. 13 of the present paper). The data presented here enlarge the known distribution of the genus by adding the area of the Shelikhov Bay (Sea of Okhotsk) and increase the number of species described in the genus. Among the representatives of Calcigorgia, C. japonica Dautova, 2007 has the southernmost distribution as it was recorded at $39^{\circ} 35^{\prime} \mathrm{N}, 135^{\circ} 01^{\prime} \mathrm{E}$ in the Sea of Japan (Dautova 2007). The other species of the genus have only been found north of this point (Dautova 2008, 2011, 2018b; Matsumoto et al. 2019). As a result, the genus Calcigorgia can be characterized as a cold-water (deepwater) group of gorgonians confined to the temperate Northern Pacific (Fig. 13).

A wide distribution is relatively common and accepted for tropical shallow Octocorallia genera and species (Roberts et al. 2006; Fabricius \& Alderslade 2001). The widely distributed tropical and temperate shallow corals, such as Sinularia, Lobophytum, and nephtheids are well distributed by larval dispersal or vicariance events. Several species are able to disperse for long distances because their pelagic larvae can colonize new and distant regions (Hudges et al. 2000; Harii et al. 2002; Kahng et al. 2011).

For deep-water Octocorallia, primarily brooders with swimming planktonic larvae, little is known regarding duration of their larval life, but the role of currents in their dispersal inevitably remains highly significant (Cordes et al. 2001; Roberts et al. 2006; Watling et al. 2011; Beazley \& Kenchington 2012; Pérez et al. 2016). The possible influence of currents, the East Kamchatka Current or the Oyashio, may be promising for understanding the dispersal of cold-water Octocorallia but has never been studied. The contemporary system of oceanic currents in the Northern Pacific suggests that there could be connections between the Octocorallia faunas of the Aleutian/Alaskan and Far East seas (Fig. 13). The Alaskan Stream moves south-westward along the Aleutian Islands as the western boundary current of the Alaska Gyre. It formes the Bering Sea Gyre in the deep part of the Bering Sea and becomes the East Kamchatka Current. This current moves south-westward along the east coast of the Kamchatka Peninsula and the Kurile Islands (naming the Oyashio Current south of the Bussol Strait, Ohtani 1970; Qiu 2001). However, the highest numbers of species are found in the Kurile Islands area (6 species, Fig. 13) but not in the Aleutian/Alaskan waters (4 species, Fig. 13).

The fact that the highest numbers of Calcigorgia species have been found in the Kurile Islands area, but not in the Aleutian Islands/Alaska area, contradicts the known system of the currents in the temperate Northern Pacific (Ohtani 1970; Qiu 2001; Fig. 13). It suggests that pathways for dispersal of the representatives of the genus in the Northern Pacific have to be reanalyzed. The definition of an evolutionary centre of origin for Calcigorgia species, for example in the Kurile Islands area, is a promising task to clarify the history of formation of the deep-water gorgonian fauna in the Pacific. It requires more knowledge regarding both the influence of the oceanic currents on the connectivity of coral communities and the genetic relationship between local faunistic complexes in the region.

\section{Acknowledgements}

The author thanks Drs Sergey Grebelnyi and Vladimir Lukin and the staff of the Research Vessels Akademik Oparin and Tikhookeansky for their valuable contribution to finding the new species described in the present paper. This work was partly sponsored by the Asia-Pacific Network for the Global Change Research (APN) grant CAF2016-RR08-CMY-Dautova.

\section{References}

Auster P.J., Moore J., Heinonen K.B. \& Watling L. 2005. A habitat classification scheme for seamount landscapes: assessing the functional role of deep-water corals as fish habitat. In: Freiwald A. \& Roberts J.M. (eds) Cold-Water Corals and Ecosystems: 761-769. Springer-Verlag, Berlin/Heidelberg. https://doi.org/10.1007/3-540-27673-4_40 
Baco A.R. \& Shank T.M. 2005. Population genetic structure of the Hawaiian precious coral Corallium lauuense (Octocorallia: Coralliidae) using microsatellites. In: Freiwald A. \& Roberts J.M. (eds) ColdWater Corals and Ecosystems: 663-678. Springer-Verlag, Berlin/Heidelberg.

https://doi.org/10.1007/3-540-27673-4_33

Baillon S., Hamel J.F., Wareham V.E. \& Mercier A. 2012. Deep cold-water corals as nurseries for fish larvae. Frontiers in Ecology and the Environment 10 (7): 351-356. https://doi.org/10.1890/120022

Bayer F.M. 1981. Key to the genera of Octocorallia exclusive of Pennatulacea (Coelenterata: Anthozoa), with diagnoses of new taxa. Proceedings of the Biological Society of Washington 94 (3): 902-947.

Bayer F.M., Grasshoff M. \& Verseveldt J. 1983. Illustrated Trilingual Glossary of Morphological and Anatomical Terms Applied to Octocorallia. E.J. Brill/Dr. W. Backhuys, Leiden.

Beazley L.I. \& Kenchington E.L. 2012. Reproductive biology of the deep-water coral Acanella arbuscula (Phylum Cnidaria: class Anthozoa: Order Alcyonacea), northwest Atlantic. Deep Sea Research Part I: Oceanographic Research Papers 68: 92-104. https://doi.org/10.1016/j.dsr.2012.05.013

Broch H. 1935. Oktokorallen des nördlichsten Pazifischen Ozeans und ihre Beziehungen zur atlantischen Fauna. Avhandlinger utgitt av det Norske videnskaps-akademi i Oslo, Matematisk-naturvidenskapelig klasse. 1935: 1-53.

Buhl-Mortensen L. \& Mortensen P.B. 2004. Crustaceans associated with the deep-water gorgonian corals Paragorgia arborea (L., 1758) and Primnoa resedaeformis (Gunn., 1763). Journal of Natural History 38: 1233-1247. https://doi.org/10.1080/0022293031000155205

Buhl-Mortensen L. \& Mortensen P.B. 2005. Distribution and diversity of species associated with deepsea gorgonian corals off Atlantic Canada. In: Freiwald A. \& Roberts J.M. (eds) Cold-Water Corals and Ecosystems: 749-879. Springer-Verlag, Berlin/Heidelberg. https://doi.org/10.1007/3-540-27673-4_44

Buhl-Mortensen P., Buhl-Mortensen L. \& Purser A. 2016. Trophic ecology and habitat provision in cold-water coral ecosystems. In: Rossi S., Gori A. \& Orejas Saco del Valle C. (eds) Marine Animal Forests: 1-26. Springer, Cham. https://doi.org/10.1007/978-3-319-17001-5_20-1

Cairns S.D. \& Hourigan T.F. 2017. A Comprehensive List of Known Deep-Sea Corals Occurring in the EEZ of the United States and its Possessions.

Available from https://repository.si.edu/handle/10088/35001 [accessed 14 Jun. 2019].

Cordes E.E., Nybakken J.W \& VanDykhuizen G. 2001. Reproduction and growth of Anthomastis ritteri (Octocorallia: Alcyonacea) from Monterey Bay California, USA. Marine Biology 138 (3): 491-501. https://doi.org/10.1007/s002270000470

Dautova T.N. 2007. Gorgonians (Anthozoa: Octocorallia) of the Northwestern Sea of Japan. Russian Journal of Marine Biology 33 (5): 297-304. https://doi.org/10.1134/S1063074007050045

Dautova T.N. 2008. Distributional patterns of the octocorals in the Indo-West Pacific and the species identification problem: what taxa could be the indicators? Marine Biodiversity and bioresources of the North-Eastern Asia. In: Lutaenko K.A. (ed.) Proceedings of the International APN Conference, 21-22 October, Cheju, Korea: 24-33.

Dautova T.N. 2011. Pathways for dispersal of the octocorals in the East Asia seas - inter-faunal connectivity and centers of biodiversity. Bulletin of the Far East Branch of the Russian Academy of Sciences 158: 31-39. [In Russian with English abstract].

Dautova T.N. 2012. New findings of Paragorgia arborea (Linnaeus, 1758) (Anthozoa: Octocorallia) in the northwestern Pacific Ocean. Russian Journal of Marine Biology 38 (5): 352-362. 
Dautova T.N. 2018a. Deep-water Octocorallia (Cnidaria: Anthozoa) of the temperate Northern Pacific: Notes on the distribution and new bathyal-abyssal taxa from the Sea of Okhotsk. Deep Sea Research Part II: Topical Studies in Oceanography 154: 74-86. https://doi.org/10.1016/j.dsr2.2018.04.002

Dautova T.N. 2018b. Two new species of deep-water Calcigorgia gorgonians (Anthozoa: Octocorallia) from the Kurile Islands, Sea of Okhotsk, with a review of distinctive characters of the known species of the genus. European Journal of Taxonomy 408: 1-22. https://doi.org/10.5852/ejt.2018.408

Fabricius K.E. \& Alderslade P. 2001. Soft Corals and Sea Fans: a Comprehensive Guide to the Tropical Shallow Water Genera of the Central-West Pacific, the Indian Ocean and the Red Sea. Australian Institute of Marine Science, Townsville.

Harii S., Kayanne H., Takigawa H., Hayashibara T. \& Yamamoto M. 2002. Larval survivorship, competency periods and settlement of two brooding corals, Heliopora coerulea and Pocillopora damicornis. Marine Biology 141 (1): 39-46. https://doi.org/10.1007/s00227-002-0812-y

Heifetz J., Wing B.L., Stone R.P., Malecha P.W. \& Courtney D.L. 2005. Corals of the Aleutian Islands. Fisheries Oceanography 14: 131-138. https://doi.org/10.1111/j.1365-2419.2005.00371.x

Herrera S., Baco A., Sánchez J.A. 2010. Molecular systematics of the bubblegum coral genera (Paragorgiidae, Octocorallia) and description of a new deep-sea species. Molecular Phylogenetics and Evolution 55 (1): 123-135. https://doi.org/10.1016/j.ympev.2009.12.007

Hughes T.P., Baird A.H., Dinsdale E.A., Moltschaniwskyj N.A., Pratchett M.S., Tanner J.E. \& Willis B.L. 2000. Supply-side ecology works both ways: the link between benthic adults, fecundity, and larval recruits. Ecology 81 (8): 2241-2249. https://doi.org/10.2307/177111

Kahng S.E., Benayahu Y. \& Lasker H.R. 2011. Sexual reproduction in octocorals. Marine Ecology Progress Series 443: 265-283. https://doi.org/10.3354/meps09414

Matsumoto A.K., Ofwegen L.P. van \& Byer F. 2019. A revision of the genus Calcigorgia (Cnidaria, Octocorallia, Acanthogorgiidae) with the description of three new species. Zootaxa 4571 (1): 001-027. https://doi.org/10.11646/zootaxa.4571.1.1

Miyamoto M., Kiyota M., Hayashibara T., Nonaka M., Imahara Yu. \& Tachikawa H. 2017. Megafaunal composition of cold-water corals and other deep-sea benthos in the southern Emperor Seamounts area, North Pacific Ocean. Galaxea 19 (1): 19-30. https://doi.org/10.3755/galaxea.19.1_19

Nutting C.C. 1912. Descriptions of the Alcyonaria collected by the U.S. Fisheries steamer "Albatross," mainly in Japanese waters, during 1906. Proceedings of the Unated.States Natural Museum 43: 1-104. https://doi.org/10.5962/bhl.title.49593

Ohtani K. 1970. Relative transport in the Alaskan Stream in winter. Journal of Oceanography 26 (5): 271-282. https://doi.org/10.1007/BF02769468

Parrish F.A. \& Baco A.R. 2007. State of deep coral ecosystems in the U.S. Pacific islands region: Hawaii and the U.S. Pacific territories. In: Lumsden S.E., Hourigan T.F., Bruckner A.W. \& Dorr G. (eds) The State of Deep Coral Ecosystems of the United States. NOAA Technical Memorandum CRCP-3: 155194. Silver Spring, MD.

Parrish F.A., Baco-Taylor A., Kelley C., Cairns S.D. \& Hourigan T. F. 2017. Deep-Sea Coral Taxa in the Hawaiian Archipelago and other US Pacific Islands: Depth and Geographical Distribution. Available from https://repository.si.edu/handle/10088/34998 [accessed 14 Jun. 2019].

Pérez C.D., de Moura Neves B., Cordeiro R.T., Williams G.C. \& Cairns S. D. 2016. Diversity and distribution of Octocorallia. In: Goffredo S. \& Dubinsky Z. (eds) The Cnidaria, Past, Present and Future: 109-123. Springer International Publishing, Cham. 
Qiu B. 2001. Kuroshio and Oyashio currents. In: Steele J.H., Thorpe S.A. \& Turekian K.K. (eds) Ocean Currents: A Derivative of the Encyclopedia of Ocean Sciences: 61-72. Academic Press. https://doi.org/10.1006/rwos.2001.0350

Roberts J.M., Wheeler A.J. \& Freiwald A. 2006. Reefs of the deep: The biology and geology of coldwater coral ecosystems. Science 312: 543-547. https://doi.org/10.1126/science.1119861

Stone R.P. \& Cairns S.D. 2017. Deep-Sea Coral Taxa in the Alaska Region: Depth and Geographical Distribution. Available from https://repository.si.edu/handle/10088/34994 [accessed 14 Jun. 2019].

Watling L., France S.C., Pante E. \& Simpson A. 2011. Biology of deep-water octocorals. In: Lesser M. (ed.) Advances in Marine Biology 60: 41-122. Academic Press, London, New York.

https://doi.org/10.1016/B978-0-12-385529-9.00002-0

Williams G.C. 2011. The global diversity of sea pens (Cnidaria: Octocorallia: Pennatulacea). PLoS ONE 6(7): e22747. https://doi.org/10.1371/journal.pone.0022747

Wing B.L. \& Barnard D.R. 2004. A field guide to Alaskan corals. U.S. US Department of Commerce, National Oceanic and Atmospheric Administration, National Marine Fisheries Service, Alaska Fisheries Science Center. NMFS-AFSC-146.

Zapata-Guardiola R. \& López-González P.J. 2010. Two new gorgonian genera (Octocorallia: Primnoidae) from Southern Ocean waters. Polar Biology 33 (3):313-320. https://doi.org/10.1007/s00300-009-0707-1

Manuscript received: 12 July 2018

Manuscript accepted: 9 June 2019

Published on: 10 September 2019

Topic editor: Rudy CAM Jocque

Desk editor: Radka Rosenbaumová

Printed versions of all papers are also deposited in the libraries of the institutes that are members of the EJT consortium: Muséum national d'Histoire naturelle, Paris, France; Meise Botanic Garden, Belgium; Royal Museum for Central Africa, Tervuren, Belgium; Royal Belgian Institute of Natural Sciences, Brussels, Belgium; Natural History Museum of Denmark, Copenhagen, Denmark; Naturalis Biodiversity Center, Leiden, the Netherlands; Museo Nacional de Ciencias Naturales-CSIC, Madrid, Spain; Real Jardín Botánico de Madrid CSIC, Spain; Zoological Research Museum Alexander Koenig, Bonn, Germany; National Museum, Prague, Czech Republic. 